\title{
Clusterin facilitates apoptotic cell clearance and prevents apoptotic cell-induced autoimmune responses
}

\author{
P Cunin ${ }^{1,2,3,4,11}$, C Beauvillain ${ }^{1,2,3,4,5,11}$, C Miot ${ }^{1,2,3,4}$, J-F Augusto ${ }^{1,2,3,4,6}$, L Preisser ${ }^{1,2,3,4}$, S Blanchard ${ }^{1,2,3,4,5}$, P Pignon ${ }^{1,2,3,4}$, \\ M Scotet ${ }^{1,2,3,4}$, E Garo $^{1,2,3,4}$, I Fremaux ${ }^{1,2,3,4}$, A Chevailler ${ }^{1,2,3,4,5}$, J-F Subra ${ }^{1,2,3,4,6}$, P Blanco $^{7,8,9}$, MR Wilson ${ }^{10}$, P Jeannin ${ }^{1,2,3,4,5,12}$ and \\ Y Delneste ${ }^{*, 1,2,3,4,5,12}$
}

Clusterin (Clu), an extracellular chaperone, exhibits characteristics of soluble innate immunity receptors, as assessed by its ability to bind some bacteria strains. In this study, we report that Clu also binds specifically to late apoptotic cells but not to live, early apoptotic, or necrotic cells. Histones, which accumulate on blebs during the apoptotic process, represent privileged Clu-binding motifs at the surface of late apoptotic cells. As a consequence, Clu potentiates, both in vitro and in vivo, the phagocytosis of late apoptotic cells by macrophages. Moreover, the increased phagocytosis of late apoptotic cells induced by Clu favors the presentation and cross-presentation of apoptotic cell-associated antigens. Finally, we observed that, in a model of apoptotic cellinduced autoimmunity, and relative to control mice, $\mathrm{Clu}^{-1-}$ mice develop symptoms of autoimmunity, including the generation of anti-dsDNA antibodies, deposition of immunoglobulins and complement components within kidneys, and splenomegaly. These results identify Clu as a new molecule partner involved in apoptotic cell efferocytosis and suggest a protective role for Clu in inflammation and autoimmune diseases.

Cell Death and Disease (2016) 7, e2215; doi:10.1038/cddis.2016.113; published online 5 May 2016

Clusterin (Clu), also known as apolipoprotein $\mathrm{J}$, is a soluble $80-\mathrm{kDa}$ disulfide-linked heterodimeric glycoprotein which is highly conserved during evolution and among mammals. ${ }^{1} \mathrm{Clu}$ is abundant in physiological fluids (concentrations ranging from 100 to $300 \mu \mathrm{g} / \mathrm{ml}$ in human serum $)^{2-4}$ and is induced in response to a wide variety of tissue injuries. Clu has chaperone activity and is a functional homolog to small heatshock proteins. ${ }^{5,6}$ It binds hydrophobic domains of numerous non-native proteins and targets them for receptor-mediated internalization and lysosomal degradation. Clu also interacts with a broad spectrum of molecules (such as lipids, components of the complement system, amyloid-forming proteins, immunoglobulins $)^{7,8}$ and has been suggested to regulate several functions, such as complement activity, cellcell and cell-substratum interactions, and cell proliferation/ survival. ${ }^{1}$ In various diseases, an accumulation of Clu has been reported in the injured organs. , $^{9,10}$

Clu also interacts with different immune molecules; however, its potential role in immune responses remains unclear. Clu binds to some bacteria (Staphylococcus aureus and some Staphylococcus epidermidis strains) and bacterial proteins (such as the Streptococcus pyogenes extracellular protein
SIC), ${ }^{11-13}$ suggesting that it may modulate antimicrobial responses. Moreover, Clu limits the severity of induced autoimmune myocarditis ${ }^{14}$ and pancreatitis. ${ }^{15}$ Finally, the levels of circulating $\mathrm{Clu}$ in systemic lupus erythematosus, ${ }^{16}$ as well as the expression of Clu mRNA in the synovium of rheumatoid arthritis patients, are decreased. ${ }^{17}$

Phagocytosis of dying cells, a process called efferocytosis, is a complex mechanism that involves (i) exposure at the apoptotic cell surface of phosphatidylserine (PS) and membrane molecules that are altered during the apoptotic process, ${ }^{18}$ and (ii) endocytic receptors expressed by phagocytes, such as members of the scavenger receptor family, ${ }^{19}$ vitronectin receptors, ${ }^{20} \mathrm{Fc}$ receptors, ${ }^{21} \mathrm{MER},{ }^{22}$ TIM-1 and $\mathrm{TIM}-4,{ }^{23}$ and CD91. ${ }^{24}$ Soluble receptors (also called opsonins), such as C1q, mannose-binding lectin (MBL), ${ }^{25}$ and milk fat globule-EGF factor 8 (MFG-E8), ${ }^{26}$ bind to apoptotic cells and act as bridging molecules to favor their internalization by phagocytes. In a non-inflammatory environment, a rapid and efficient clearance of apoptotic cells maintains immune homeostasis and avoids the initiation of autoimmune responses. $^{27,28}$ In contrast, a dysfunction in the clearance of apoptotic cells may result in the release of danger molecules

\footnotetext{
${ }^{1}$ Université d'Angers, Angers, France; ${ }^{2}$ Unit 892, Inserm, CHU d'Angers, Angers, France; ${ }^{3} \mathrm{CNRS}$, Unit 6299, Angers, France; ${ }^{4}$ LabEx IGO "Immuno-Graft-Onco", Angers, France; ${ }^{5}$ Laboratoire d'Immunologie et d'Allergologie, CHU Angers, Angers, France; ${ }^{6}$ Service de Néphrologie-Dialyse-Transplantation, $\mathrm{CHU}$ Angers, Angers, France; ${ }^{7}$ Université Victor Segalen, Bordeaux, France; ${ }^{8} \mathrm{CNRS}$ Unit 5164, Bordeaux, France; ${ }^{9} \mathrm{CHU}$ Bordeaux, Bordeaux, France and ${ }^{10}$ School of Biological Sciences, Illawarra Health and Medical Research Institute, University of Wollongong, Wollongong, New South Wales, Australia

*Corresponding author: Y Delneste, Unit 892, Inserm, CHU d'Angers, IRIS, 4 rue Larrey, Angers 49933, France. Tel: +33(0)244 688 300; Fax: +33(0)244 688 594; E-mail: yves.delneste@inserm.fr

${ }^{11}$ These authors contributed equally to this study.

${ }^{12}$ These authors supervised this study equally.

Abbreviations: Ann V, annexin V; APC, antigen-presenting cells; Clu, clusterin; CRP, C-reactive protein; HSA, human serum albumin; M $\varphi$, macrophages; MBL, mannose-binding lectin; Ova, ovalbumin; PI, propidium iodide; PRR, pattern recognition receptor; RA, rheumatoid arthritis; SAP, serum amyloid P component

Received 17.12.15; revised 21.4.16; accepted 04.4.16; Edited by H-U Simon
} 
a

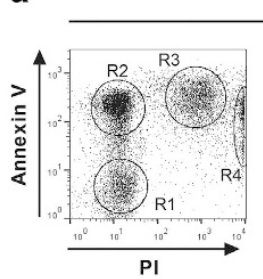

Apoptotic cells

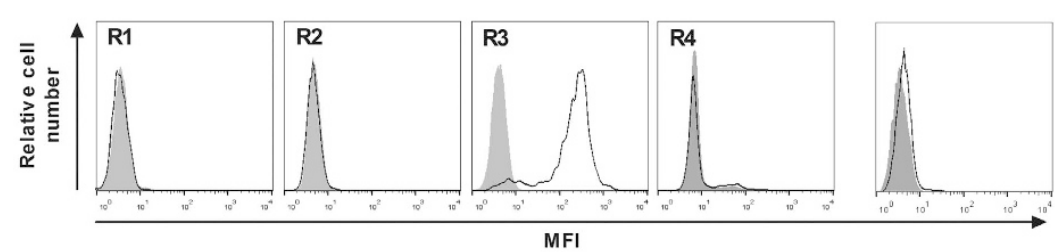

b

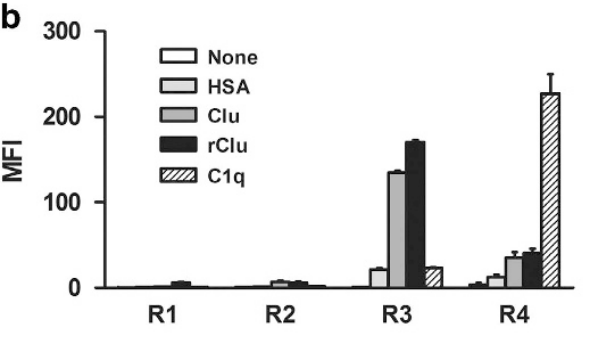

c

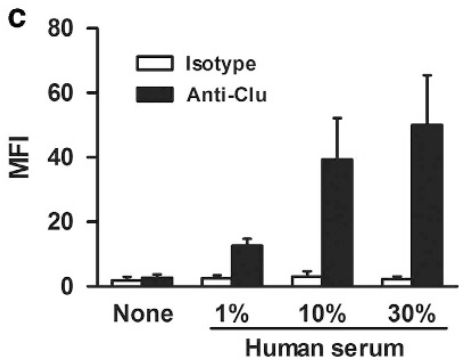

d

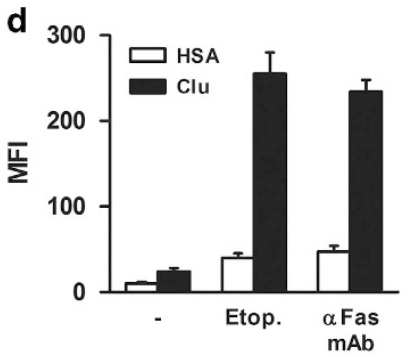

Figure 1 Clu binds to late apoptotic cells. (a) Left panel, analysis of spontaneous apoptosis of human neutrophils after culture in $1 \%$ FCS culture medium and staining with PI and APC-labeled Ann V. Flow cytometry analysis allowed to identify four populations corresponding to viable (Ann $\mathrm{V}^{-} \mathrm{Pl}^{-} ; \mathrm{R} 1$ ), early apoptotic (Ann $\mathrm{V}^{+} \mathrm{PI}^{-}$; $\mathrm{R} 2$ ), late apoptotic (Ann $\mathrm{V}^{+} \mathrm{Pl}^{+} ; \mathrm{R} 3$ ), and necrotic cells (Ann $\mathrm{V}^{+/}-\mathrm{P}^{\text {high; }}$ R4), respectively. Middle panels, dying neutrophils were incubated or not with $1 \mu \mathrm{M}$ OG-Clu; the binding of Clu to R1-R4 populations was evaluated by flow cytometry. Right panel, binding of OG-Clu to heat-induced necrotic neutrophils. Results are representative of five independent experiments. (b) Neutrophils, at different apoptosis stages (R1-R4), were incubated with $1 \mu \mathrm{M}$ OG-HSA, OG-Clu, OG-rClu, or OG-C1q. Binding was analyzed by flow cytometry. Results are expressed in MFI values, mean \pm S.E.M., $n=5$. (c) Late apoptotic neutrophils were incubated with increasing concentration of human serum and stained with an anti-Clu or isotype-matched mAb. Bound Abs were detected by flow cytometry using a FITC-labeled anti-mouse lg Ab. Results are expressed in MFI values, mean \pm S.E.M., $n=4$. (d) Binding of OG-Clu to late apoptotic Jurkat T cells. The apoptosis was induced with $20 \mu \mathrm{g} / \mathrm{ml}$ etoposide or $20 \mathrm{ng} / \mathrm{ml}$ anti-FAS mAb. Results are expressed in MFI values, mean \pm S.E.M., $n=4$

(referred to as danger-associated molecular patterns) that may favor the initiation of autoimmune responses. . $^{27,28}$

The pivotal role played by soluble molecules in apoptotic cell clearance and, consequently the outcome of immune responses to apoptotic cell antigens, has been clearly evidenced in opsonin-deficient mice. For example, mice deficient in MFG-E8, C1q, or serum amyloid P component (SAP) show impaired clearance of apoptotic cells and develop a lupus-like disease characterized by elevated levels of autoantibodies and glomerulonephritis. ${ }^{29-31}$

Some soluble innate immunity receptors involved in microbial recognition have also been implicated in apoptotic cell clearance. ${ }^{19}$ As Clu binds to microbial moieties, ${ }^{9-11}$ we investigated whether Clu might also mediate apoptotic cell clearance by phagocytes.

\section{Results}

Clu binds to late apoptotic cells. We first evaluated the ability of recombinant human Clu to bind to spontaneously dying human neutrophils. As previously described, ${ }^{32}$ four populations can be distinguished by flow cytometry, based on annexin $\mathrm{V}$ (Ann $\mathrm{V}$ ) and propidium iodide (PI) staining (Figure 1a, left panel): viable (Ann $\mathrm{V}^{-} \mathrm{PI}^{-}$, corresponding to R1), early apoptotic (Ann $\mathrm{V}^{+} \mathrm{PI}^{-}$; R2), late apoptotic (Ann $\mathrm{V}^{+}$ $\mathrm{PI}^{+} ; \mathrm{R} 3$ ), and secondary necrotic cells (Ann $\left.\mathrm{V}^{+/}-\mathrm{PI}^{\text {high }} ; \mathrm{R} 4\right)$. Results showed that Oregon Green 488 (OG)-labeled Clu (OG-Clu) binds to late apoptotic (R3) and, to a low extent, to secondary necrotic neutrophils (R4), but not to viable (R1) and early apoptotic (R2) neutrophils (Figure 1a, middle panels). A low binding of OG-Clu was also detected to heat-induced necrotic neutrophils (Figure 1a, right panel). Similar binding profiles were obtained using purified and recombinant Clu revealed by a FITC-labeled anti-Clu $\mathrm{mAb}$ (Figure 1b). As control, ${ }^{25,33}$ OG-C1q binds preferentially to late apoptotic and secondary necrotic cells (Figure 1b). No binding of the control protein OG-HSA (human serum albumin) was observed on dying cells (Figure 1b).

We next investigated whether Clu present in human serum also binds to late apoptotic cells. Dying neutrophils were incubated with human serum and bound $\mathrm{Clu}$ was detected using a FITC-labeled anti-Clu mAb. Results showed that Clu present in human serum binds to late apoptotic cells and that the level of binding was dependent on the concentration of serum used (Figure 1c); no binding of the anti-Clu mAb on late apoptotic cells was observed in the absence of serum (Figure 1c), demonstrating that intracellular Clu does not translocate to the surface of dying cells during the apoptotic process. Finally, we observed that Clu also binds to (i) late apoptotic Jurkat cells (induced by etoposide or an anti-Fas mAb) (Figure 1d), (ii) apoptotic murine thymocytes (Supplementary Figure S1A), and (iii) tumor cells either irradiated or treated with etoposide (Supplementary Figure S1B), demonstrating that the binding of Clu to late apoptotic cells is not dependent on the cell type or on the apoptosis-inducing signal.

Clu binds to histones expressed at the surface of late apoptotic cells. The binding of OG-Clu to late apoptotic neutrophils is dose dependent, partly saturable (Figure 2a), and is inhibited in a dose-dependent manner, by unlabeled $\mathrm{Clu}$, but not by HSA (Figure 2b). Fluorescence microscopy revealed an intense staining on bleb-like structures (Figure 2c). 


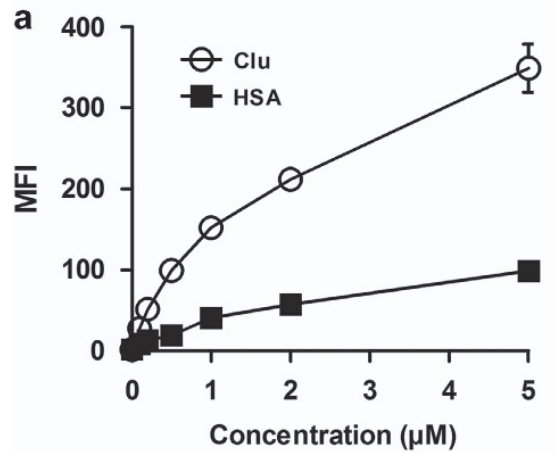

C

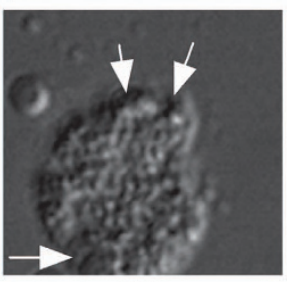

DIC

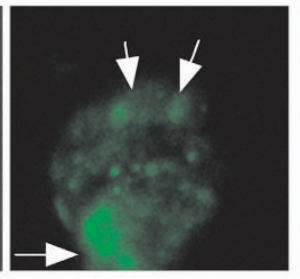

OG-Clu

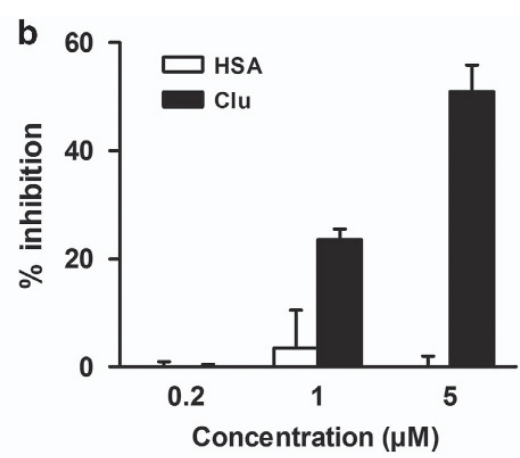

d

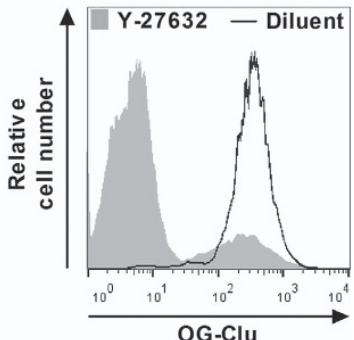

Figure 2 Clu-binding elements are localized on blebs. (a) Late apoptotic neutrophils were incubated with increasing concentrations of OG-Clu or OG-HSA; the binding was analyzed by flow cytometry. Results are expressed in MFI values, mean \pm S.E.M., $n=5$. (b) Late apoptotic neutrophils were incubated with the indicated concentrations of unlabeled Clu or HSA before addition of $1 \mu \mathrm{M} \mathrm{OG-Clu;} \mathrm{the} \mathrm{binding} \mathrm{of} \mathrm{OG-Clu} \mathrm{was} \mathrm{analyzed} \mathrm{by} \mathrm{flow} \mathrm{cytometry.} \mathrm{Results} \mathrm{are} \mathrm{expressed} \mathrm{as} \mathrm{the} \mathrm{percentages} \mathrm{of} \mathrm{inhibition,} \mathrm{mean} \pm$ S.E.M., $n=5$. (c) Differential interference contrast (DIC; left panel) and confocal fluorescence (right panel) microscopic images of late apoptotic neutrophils incubated with OGClu. Images are representative of two independent experiments. White arrows, blebs; original magnification, $\times 630$. (d) Neutrophils were incubated or not with $50 \mu \mathrm{g} / \mathrm{ml}$ Y-27632, prior to apoptosis induction. The binding of OG-Clu was evaluated by flow cytometry. Histograms are representative of three independent experiments

This binding was reduced on apoptotic neutrophils (Figure 2d), which were left to die in the presence of Y-27632, an inhibitor of membrane blebbing. ${ }^{34}$ These observations suggested the presence of Clu-binding elements at the surface of late apoptotic cells.

The apoptotic process is accompanied by cell surface alterations, such as PS externalization, membrane relocalization of intracellular components, and oxidation of membrane molecules; ${ }^{35,36}$ these motifs act as 'eat-me' molecules. In an attempt to characterize the nature of the Clu-binding motif(s), we evaluated whether a treatment with DNase, glycosidases, or pronase may modulate the binding of Clu to late apoptotic cells. DNase strongly upregulated the binding of $\mathrm{Clu}$ to apoptotic Jurkat cells (increase of $362 \pm 51 \%$; mean \pm S.E.M., $n=4$; Figures $3 a$ and $b$ ); as a control for DNase efficiency, the staining with $\mathrm{PI}$ and the binding of an anti-dsDNA mAb was lower on DNase-treated than on non-treated apoptotic cells (Figures $3 a$ and b). In contrast, pronase or glycosidases did not modulate the binding of Clu to apoptotic cells (Figure $3 b$ ); as enzyme controls, pronase and glycosidases decreased the binding on late apoptotic cells of anti-CD45RA $\mathrm{mAb} \mathrm{b}^{37}$ and of the lectin wheat germ agglutinin (WGA), ${ }^{38}$ respectively (Figure $3 b$ ). The treatment of late apoptotic cells with DNAse and pronase strongly accelerated the generation of remnant cells (data not shown), excluding evaluating the binding of Clu on apoptotic cells treated with the two enzymes. Finally, a negligible amount of Clu bound to erythrocytes treated with ionomycin (Supplementary Figure S2A), which induces phospholipid externalization, ${ }^{39}$ making unlikely a role for externalized lipids in the binding of Clu. Accordingly, no binding of Clu was detected on immobilized lipids (Supplementary Figure S2B).

The fact that DNAse increased the binding of Clu to late apoptotic cells suggested that DNA may sterically mask Clubinding elements. As genomic DNA is associated with histones, we suspected that histones might represent Clu-binding elements. A solid-phase binding assay showed that Clu binds to immobilized $\mathrm{H} 2 \mathrm{~A}, \mathrm{H} 2 \mathrm{~B}, \mathrm{H} 3$, and $\mathrm{H} 4$, and, to a lower extent, to the linker subunit $\mathrm{H} 1$ (Figure $3 \mathrm{c}$ ). As control, ${ }^{40,41} \mathrm{C}$-reactive protein (CRP) and SAP, but not HSA, also bind to histones (Figure $3 \mathrm{c}$ ). No binding of Clu to immobilized dsDNA was observed (Figure 3c); as a control, immobilized dsDNA was recognized by anti-dsDNA Abs (data not shown).

We then confirmed that histones, translocated to the surface of apoptotic cells, represent Clu-binding elements. As reported, ${ }^{36}$ histones can be detected at the surface of late apoptotic neutrophils but not on viable, early apoptotic, and necrotic neutrophils (Figure 3d). Interestingly, DNAse increased the binding of an anti-histone Ab (Supplementary Figure S2C), confirming that DNA may mask Clu-binding motifs on histones at the surface of late apoptotic cells. Finally, confocal microscopy revealed a partial colocalization between OG-Clu and histones at the surface of apoptotic cells (Figure $3 e$ ).

Clu is involved in the clearance of apoptotic cells. Opsonins act as bridging molecules to favor apoptotic cell clearance. We therefore examined whether Clu may be involved in apoptotic cell clearance using a FACS-based 
in vitro apoptotic cell engulfment assay. ${ }^{42,43}$ Macrophages $(\mathrm{M} \varphi)$ were fed with PKH67-labeled early or late apoptotic neutrophils, previously incubated or not with $\mathrm{Clu}, \mathrm{MBL}$, or HSA. Compared with the control protein HSA, Clu enhanced the phagocytosis of apoptotic cells $(69 \pm 12 \%$ increase; mean \pm S.E.M., $n=6)$ in a similar manner to MBL $(67 \pm 14 \%$ increase) (Figure 4a) used as a positive control. ${ }^{25}$ In agreement with the absence of binding to early apoptotic cells, Clu did not modulate the efferocytosis of $\mathrm{AnnV}^{+} \mathrm{PI}^{-}$ cells (Figure $4 a$ ). In order to investigate the role of seric Clu, late apoptotic neutrophils were incubated with heatinactivated human serum, either depleted or not in Clu. Depletion of Clu reduced the phagocytosis of apoptotic cells (26 $\pm 6 \%$ decrease; mean \pm S.E.M., $n=5$ ); this inhibition was
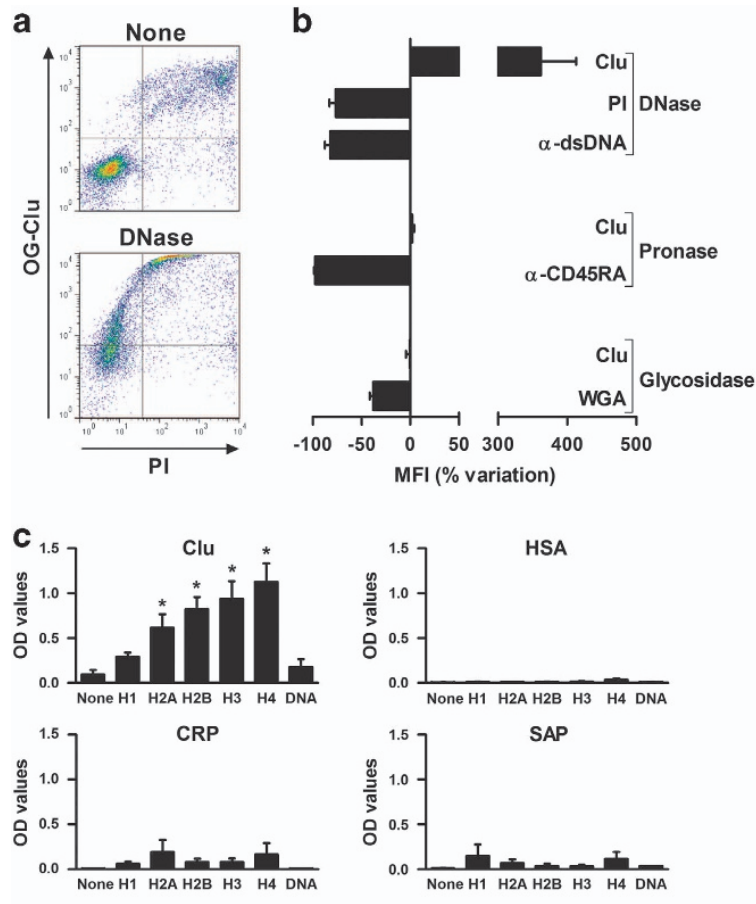

d

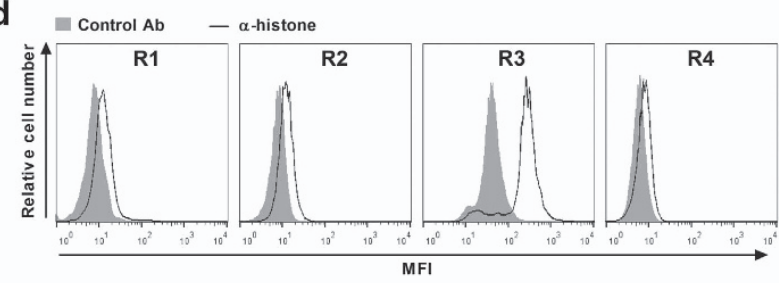

e

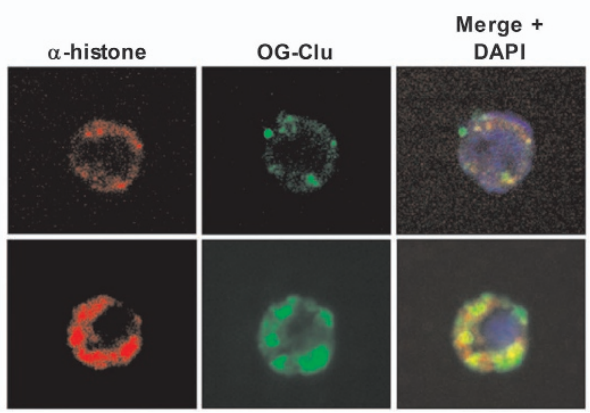

partially reversed by supplementing Clu-depleted serum with exogenous Clu (Figure 4b).

Prior to analyzing the role of Clu in the in vivo clearance of apoptotic cells, we confirmed the ability of Clu to promote the in vitro phagocytosis of apoptotic murine cells. Results showed that (i) late apoptotic thymocytes opsonized with Clu are more efficiently internalized by $\mathrm{M} \varphi$ than apoptotic cells incubated with HSA ( $46 \pm 7 \%$ increase; mean \pm S.E.M., $n=5$; Figure 4c), and (ii) that apoptotic thymocytes incubated with serum from $\mathrm{Clu}^{-1-}$ mice were less efficiently engulfed by $\mathrm{M} \varphi$ than apoptotic cells incubated with serum from wild-type (WT) mice $(12 \pm 2 \%$ decrease; mean \pm S.E.M., $n=6$; Figure $4 d)$. The in vivo role of $\mathrm{Clu}$ in apoptotic cell clearance was investigated using $\mathrm{Clu}^{-/-}$mice. In a first set of experiments, we compared, in WT and $\mathrm{Clu}^{-1-}$ mice, the clearance of dying thymocytes in which apoptosis was induced by dexamethasone sodium phosphate (Dex). ${ }^{22,44}$ Remarkably, the thymus of Dex-injected $\mathrm{Clu}^{-1-}$ mice contained approximately twofold more remnant apoptotic cells than Dex-injected WT mice $(15 \pm 3 \%$ versus $8 \pm 2 \%$; mean \pm S.E.M., $n=5$; Figure $4 \mathrm{e})$; we excluded that this observation may result from an increased sensitivity of thymocytes from $\mathrm{Clu}^{-1-}$ mice to Dex-induced apoptosis (Supplementary Figure S3A). In contrast, no difference was observed in $\mathrm{Clu}^{-1-}$ and WT mice injected with PBS (Figure 4e). In a second set of experiments, we analyzed the splenic clearance of PKH67-labeled apoptotic thymocytes injected intravenously in $\mathrm{Clu}^{-1-}$ and WT mice. Two hours after injection, the spleens from $\mathrm{Clu}^{-1-}$ mice contained more apoptotic cells than WT mice $(0.56 \pm 0.06 \%$ versus $0.44 \pm 0.03 \%$; mean \pm S.E.M., $n=4$; Figure $4 f)$; this defect was maintained $6 \mathrm{~h}$ after apoptotic cell injection (data not shown). Importantly, $\mathrm{M} \varphi$ from $\mathrm{Clu}^{-/-}$mice do not exhibit any defect in apoptotic cell phagocytosis (Supplementary Figure S3B).

Clu enhances $\mathrm{CD4}^{+}$and $\mathrm{CD}^{+}{ }^{+}$-cell responses to an apoptotic cell-associated antigen. The engulfment of apoptotic cells by phagocytes leads to the presentation of

Figure 3 Clu binds to histones expressed on late apoptotic cells. (a) Late apoptotic Jurkat T cells were treated with $500 \mu \mathrm{g} / \mathrm{ml}$ DNase prior to incubation with $1 \mu \mathrm{M}$ OG-Clu. DNase efficiency was assessed by PI staining. Dot plots are representative of four independent experiments. (b) Binding of OG-Clu to apoptotic Jurkat $T$ cells treated with $500 \mu \mathrm{g} / \mathrm{ml}$ DNase, $100 \mu \mathrm{g} / \mathrm{ml}$ pronase, or $100 \mu \mathrm{g} / \mathrm{ml}$ glycosidase. As controls of DNase, pronase, and glycosidase efficiency, binding of $\mathrm{PI}$, anti-dsDNA mAb, anti-CD45RA mAb, and FITC-labeled WGA was analyzed. Results are expressed as a percentage of variation of the binding of Clu, $\mathrm{Pl}$, anti-dsDNA mAb, anti-CD45RA mAb, and WGA on treated compared with non-treated cells, mean \pm S.E.M., $n=4$. (c) H1, H2A, H2B, H3, and $\mathrm{H} 4$ histone subunits and genomic human DNA were immobilized on a 96-well plate. Binding of biotinylated-HSA, -Clu, -CRP, and -SAP to histone subunits and DNA was determined by enzyme-linked immunosorbent assay. Results are expressed in OD values, mean \pm S.E.M.; $n=5$. ${ }^{\star} P<0.05$ compared to none (Mann-Whitney test). (d) Apoptotic neutrophils were labeled with anti-H2/H3/H4 or isotype control mAbs, before incubation with a FITClabeled anti-mouse IgG Ab. Live (R1), early apoptotic (R2), late apoptotic (R3), and necrotic neutrophils (R4) were discriminated by flow cytometry using Ann V and PI staining. Results are representative of one out four experiments. (e) Apoptotic neutrophils were incubated with OG-Clu in the presence of anti-H4 (upper panels) or anti-H2/H3/H4 mAbs (lower panels) prior to incubation with a PE-labeled anti-mouse IgG Ab. Presence of OG-Clu and histones on cell surface was assessed by confocal microscopy. DNA was stained with DAPI. Original magnification, $\times 630$. Images are representative of one of the four experiments 
a

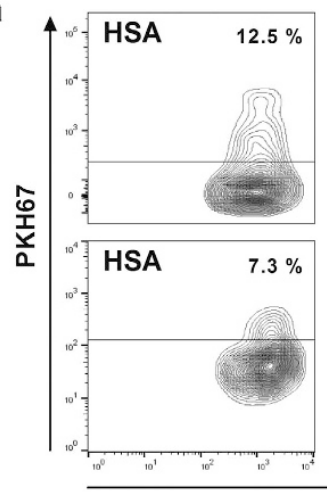

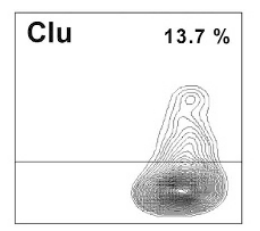

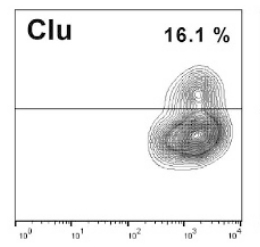

HLA-DR b

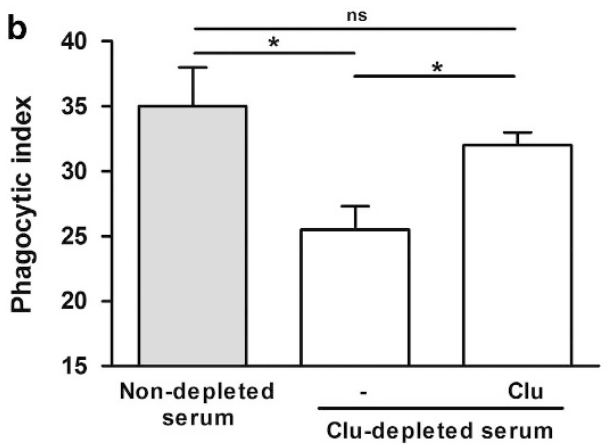

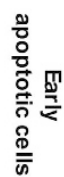
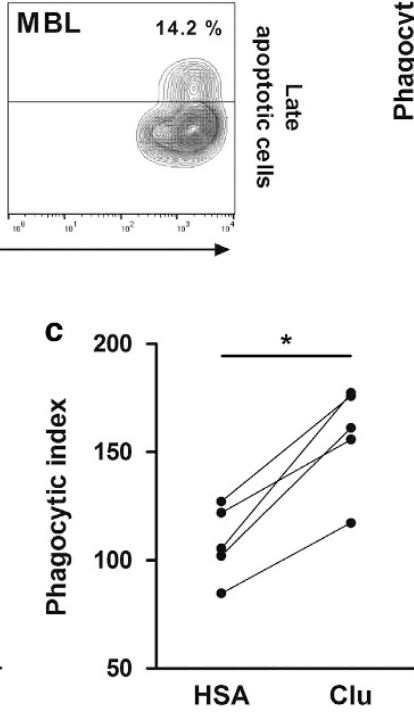
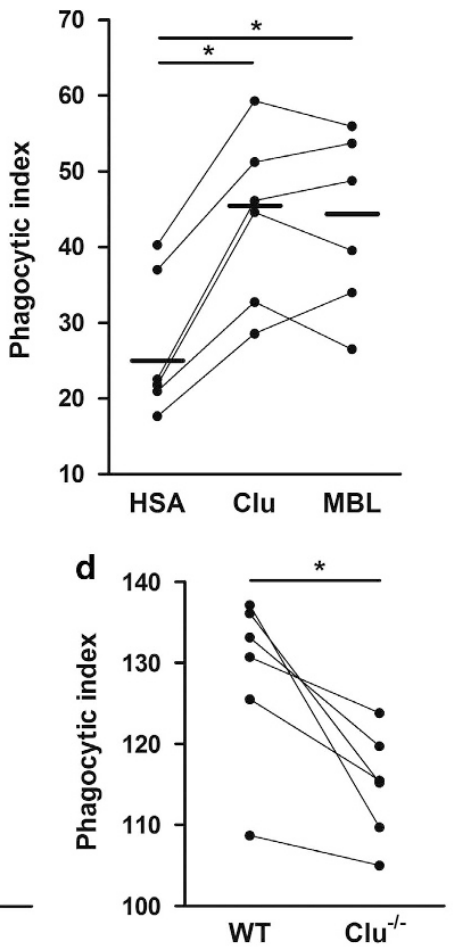

e

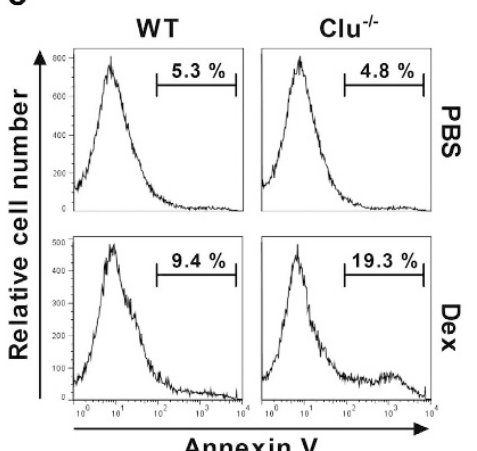

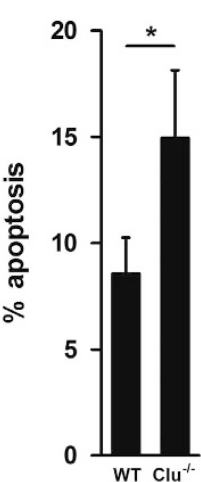

f

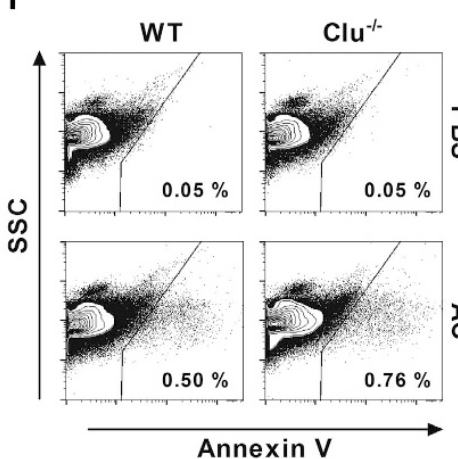

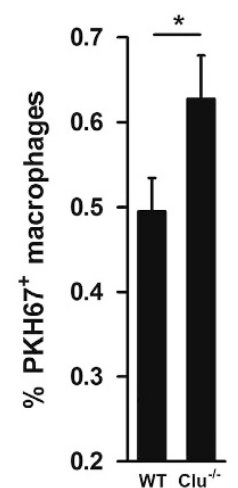

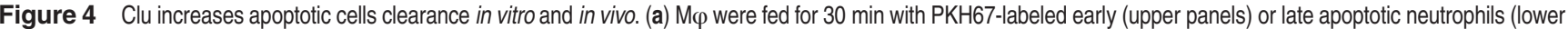
panels) (1: 10 ratio) previously opsonized or not with $1 \mu \mathrm{M}$ Clu, MBL, or HSA before incubation with APC-labeled anti-HLA DR mAb. Fluorescence was analyzed by flow cytometry. Left, contour plots are representative of two (upper panels) or six (lower panels) independent experiments; values correspond to the percentage of M $\varphi$ having engulfed dying cells. Right, results of phagocytosis assays using late apoptotic cells are expressed as a phagocytic index (see Materials and Methods); individual determinations are plotted, means are represented by horizontal bars. ${ }^{*} P \leq 0.05$. (b) $M \varphi$ were fed with PKH67-labeled late apoptotic neutrophils previously incubated in the presence of $30 \%$ (v:v) human $\mathrm{AB}^{+}$serum, depleted or not in Clu, and supplemented or not with $1 \mu \mathrm{M} \mathrm{Clu}$. Results are shown as a phagocytic index, mean \pm S.E.M.; $n=4 .{ }^{*} P \leq 0.05 ; \mathrm{NS}$, not significant. (c) BMDM were fed with PKH67-labeled late apoptotic murine thymocytes (1:5 ratio) previously opsonized with $1 \mu \mathrm{M}$ Clu or HSA before incubation with PE-labeled anti-F4/80 mAb. Fluorescence was analyzed by flow cytometry. (d) PKH67-labeled late apoptotic thymocytes were incubated with $1 \%$ serum from WT or $\mathrm{Clu}^{-1-}$ mice. The phagocytosis assay was performed as previously described. (e) $\mathrm{Clu}^{-1-}$ and WT mice $(n=5)$ were injected intraperitoneally with Dex or with PBS. After $24 \mathrm{~h}$, the frequency of Ann $\mathrm{V}^{+}$apoptotic cells in the thymus was determined by flow cytometry. Left, representative histograms are shown. Values correspond to the percentage of apoptotic cells. Right, results are expressed as the percentage of apoptotic cells, mean \pm S.E.M., $n=4 ;{ }^{*} P \leq 0.05$. (f) PKH67-labeled late apoptotic thymocytes $\left(1 \times 10^{8}\right)$ or PBS were injected intravenously in WT and $\mathrm{Clu}^{-1-}$ mice. The frequency of PKH67-positive events within splenocytes $2 \mathrm{~h}$ after injection was evaluated by flow cytometry. Left, representative dot plots are shown. Values correspond to the percentage of PKH67-positive cells. Right, results are shown as the percentage of the PKH67-positive cells, mean \pm S.E.M., $n=4 ;{ }^{*} P \leq 0.05$

apoptotic cell-derived antigens, a process contributing to the maintenance of peripheral tolerance. ${ }^{45-47}$ We therefore analyzed whether Clu might promote apoptotic cell antigen presentation to $\mathrm{CD}^{+}$and $\mathrm{CD}^{+} \mathrm{T}$ cells. Murine thymocytes were loaded with ovalbumin (Ova) prior to apoptosis induction (Ova-Apopt). In a first set of experiments, dendritic cells (DCs) were incubated with Ova-Apopt previously incubated with Clu or HSA, before culture with Ova-specific OT1 $\mathrm{CD}^{+}$or OT2 $\mathrm{CD}^{+}{ }^{+} \mathrm{T}$ cells. Results showed that the opsonization of Ova-Ova-Apopt with Clu enhanced the production of IL-2 by OT1 and OT2 T cells, compared with Ova-Ova-Apopt incubated with HSA $(200 \pm 64 \%$ and 

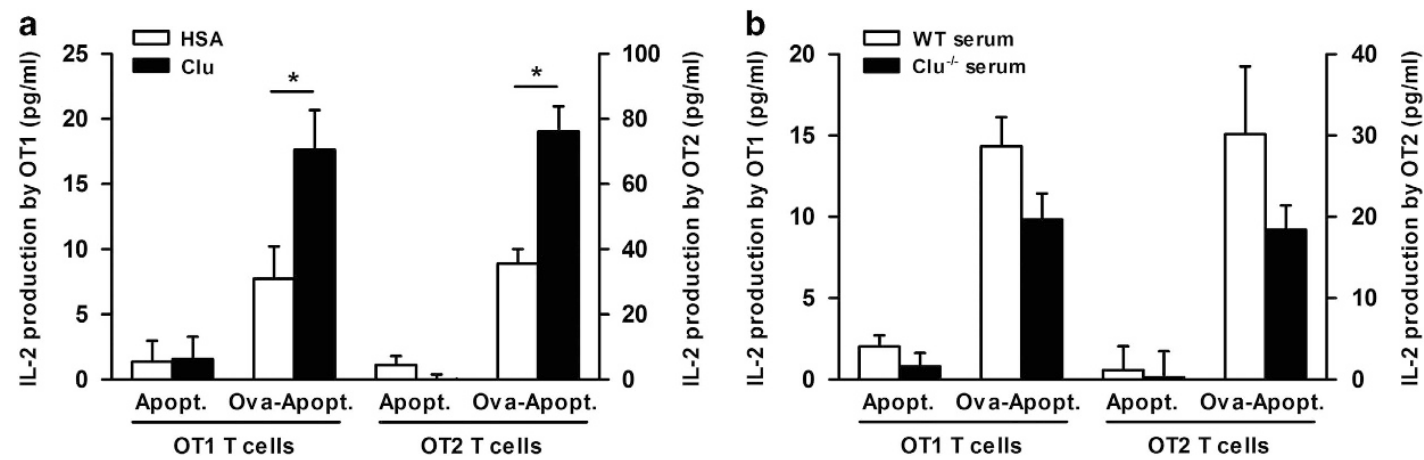

Figure 5 Clu enhances the presentation of apoptotic cell-associated antigen. Thymocytes from Swiss mice were pulsed or not with $35 \mu \mathrm{M}$ Ova and induced to die by serum deprivation. Apoptotic thymocytes pulsed with Ova (Ova-Apopt) or not (Apopt) were incubated for $30 \mathrm{~min}$ (a) with Clu or albumin or (b) with $10 \%$ serum from WTor Clu ${ }^{-1-}$ mice before culture with BMDCs and OT1 or OT2 cells. IL-2 was quantified in the 24-h supernatants by enzyme-linked immunosorbent assay. Results are expressed in pg/ml, mean \pm S.E.M.; $n=6 ;{ }^{*} P \leq 0.05$

$121 \pm 19 \%$ increase, respectively; mean \pm S.E.M., $n=6$; Figure 5a). In a second set of experiments, DCs were incubated with Ova-Ova-Apopt previously incubated with $10 \%$ serum from $\mathrm{Clu}^{-1-}$ or WT mice before culture with Ovaspecific T cells. The levels of IL-2 produced by OT1 and OT2 $\mathrm{T}$ cells were lower with Ova-Ova-Apopt incubated with serum from $\mathrm{Clu}^{-1-}$ mice versus serum from WT mice (32 $\pm 8 \%$ and $34 \pm 9 \%$ decrease, respectively; mean \pm S.E.M., $n=4$; Figure $5 b$ ).

Clu-deficient mice are sensitive to apoptotic cell-induced autoimmunity. A defect in apoptotic cell clearance may trigger an autoimmune response. ${ }^{27,44,48}$ We thereby postulated that the absence of Clu might predispose mice to apoptotic cell-induced autoimmunity. We compared, in $\mathrm{Clu}^{-/-}$ and WT mice, the appearance of signs of autoimmunity in a model of mild autoimmune response induced by repeated injections of apoptotic cells. ${ }^{47,49}$ Results showed that, 2 weeks after the first injection of apoptotic cells, the levels of IgG anti-dsDNA $\mathrm{Ab}$ were increased in $\mathrm{Clu}^{-1-}$ mice compared with WT mice $(2638 \mathrm{U} / \mathrm{ml} \pm 282$ versus $1823 \mathrm{U} / \mathrm{ml} \pm 450$, respectively; Figure 6a). In contrast to WT mice, which only developed a slight and transient upregulation 6 weeks after the first injection of apoptotic cells, the levels of IgG anti-dsDNA Abs were significantly higher and maintained elevated in $\mathrm{Clu}^{-1-}$ mice, 10 weeks after the first injection of apoptotic cells (Figure 6a). The basal levels of anti-dsDNA Abs remained stable in non-injected $\mathrm{Clu}^{-/-}$mice and were equivalent to the ones in WT mice, although a slight increase was observed as the animal aged (Figure 6a). Interestingly, no difference in the kinetics and amplitude of IgG anti-Ova Ab titers was observed between $\mathrm{Clu}^{-1-}$ and WT mice immunized with Ova (Supplementary Figure S4A), suggesting that the induction of anti-dsDNA Abs in $\mathrm{Clu}^{-/}$ mice did not result from an abnormal capacity to mount a humoral response. Interestingly, glomerular IgG and complement component $\mathrm{C} 4$ deposits were observed in $\mathrm{Clu}^{-/-}$but not in WT mice, 10 weeks after injection of apoptotic cells (Figure 6b); no deposit was observed in $\mathrm{Clu}^{-/-}$and WT mice injected with PBS (Supplementary Figure S4B). Upon injection of apoptotic cells, the spleen weight of $\mathrm{Clu}^{-1-}$ mice was slightly but significantly increased, compared with WT mice (increase of $38 \pm 10 \%$; mean \pm SEM, $n=4$ ), 8 weeks after the first injection of apoptotic cells (Figure 6c). Moreover, 10 weeks after the first injection of apoptotic cells, relative to WT mice, the liver expression of SAP mRNA was enhanced in $\mathrm{Clu}^{-/-}$mice (Figure 6d).

The generation of class-switched IgG autoantibodies in $\mathrm{Clu}^{-1-}$ mice suggested the role of T cells. We first analyzed the frequency of naive (CD44- $\left.{ }^{-} D 62 L^{\text {high }}\right)$, central memory $\left(\mathrm{CD} 44^{+} \mathrm{CD}^{2} \mathrm{~L}^{\text {high }}\right)$, and effector memory $\left(\mathrm{CD} 44^{+}\right.$ $\left.\mathrm{CD}_{2} \mathrm{~L}^{\text {low }}\right)^{50} \mathrm{CD}^{+}$and $\mathrm{CD}^{+} \mathrm{T}$ cells. Results showed an increase in the frequency of $\mathrm{CD} 44^{+} \mathrm{CD} 62 \mathrm{~L}^{\text {low }}$ cells within both $\mathrm{CD}^{+}$and $\mathrm{CD}^{+}$T-cell subsets, 10 weeks after the first injection of apoptotic cells (Figure $7 \mathrm{a}$ ). Moreover, the ratio of $\mathrm{CD}_{4} 4^{+} \mathrm{CD}_{22} \mathrm{~L}^{\text {low }}$ and $\mathrm{CD} 44^{+} \mathrm{CD} 62 \mathrm{~L}^{\text {high }}$ cells among CD4 ${ }^{+}$ and $\mathrm{CD}^{+} \mathrm{T}$ cells were significantly increased in the lymph nodes of $\mathrm{Clu}^{-1-}(1.10 \pm 0.07$ and $0.28 \pm 0.07$, respectively; mean \pm S.E.M., $n=5)$ compared with WT mice $(0.70 \pm 0.14$ and $0.14 \pm 0.03$, respectively) (Figure $7 \mathrm{~b}$ ). The total numbers of $\mathrm{CD}^{+}$and $\mathrm{CD}^{+} \mathrm{T}$ cells, $\mathrm{B}$ cells, $\mathrm{M} \varphi$, and $\mathrm{DCs}$ (Supplementary Figure S5A), as well as the frequency of regulatory, memory, naive, and activated $T$ cells, and of activated B cells (Supplementary Figure S5B), were equivalent in the lymph nodes and spleens of non-treated 12-weekold WT and $\mathrm{Clu}^{-1-}$ mice. We next determined whether the increased percentage of $\mathrm{CD} 44^{+} \mathrm{CD}_{2} \mathrm{~L}^{\text {low }} \mathrm{CD}^{+}$and $\mathrm{CD} 4^{+}$ $\mathrm{T}$ cells in apoptotic cell-injected $\mathrm{Clu}^{-1-}$ mice had functional implications. Upon stimulation with phorbol myristic acetate (PMA) plus ionomycin, lymph node $\mathrm{CD}^{+}$and $\mathrm{CD}^{+} \mathrm{T}$ cells from $\mathrm{Clu}^{-1-}$ mice produced significantly more IL-2 than cells from WT mice (Figure 7c), while only $\mathrm{CD}^{+} \mathrm{T}$ cells from $\mathrm{Clu}^{-1-}$ mice produced significantly more IFN- $\gamma$ than cells from WT mice (Figure 7d).

\section{Discussion}

Even though suspected, the potential role of Clu in immune homeostasis remains largely unexplored. We report here that Clu promotes the clearance of late apoptotic cells via its unique capacity to bind to histones translocated to the surface of apoptotic cells. Accordingly, $\mathrm{Clu}^{-1-}$ mice develop signs of autoimmunity in a model of apoptotic cell-induced autoimmunity. These results identify $\mathrm{Clu}$ as a new bridging 


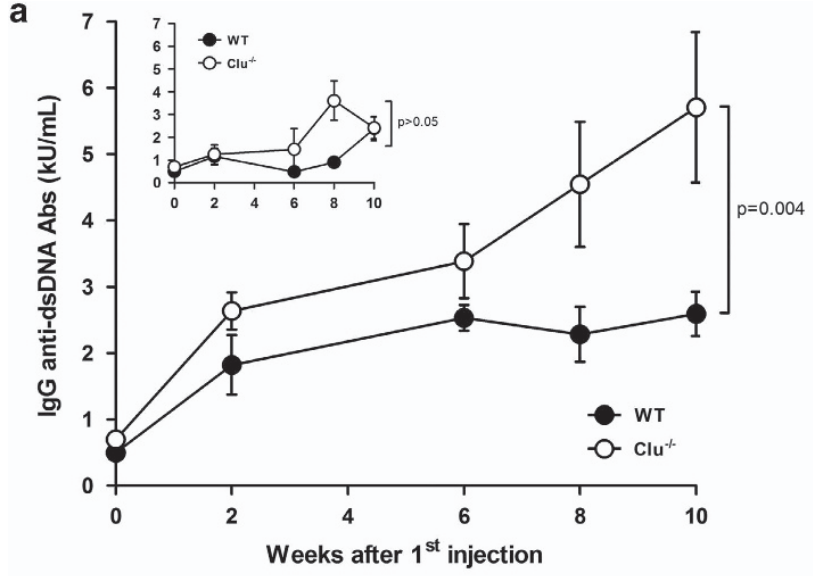

b
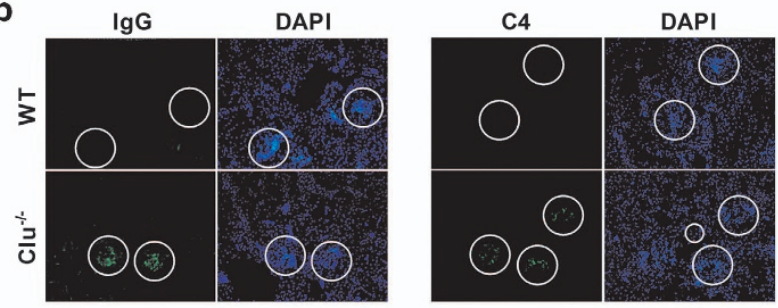

C

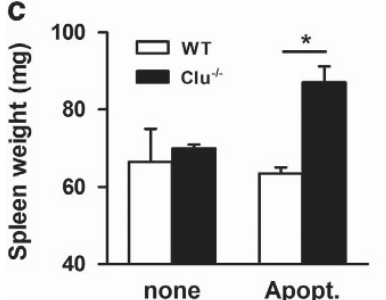

d

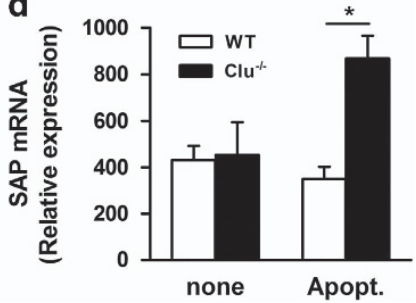

Figure 6 Clu-deficient mice develop autoimmune symptoms in response to apoptotic cells. Aged-matched $\mathrm{Clu}^{-1-}$ and WT mice were injected with apoptotic cells once a week for 5 weeks. Two weeks after the first injection of apoptotic cells, 4-6 mice per group were killed bimonthly. (a) Circulating IgG anti-dsDNA antibody levels were quantified. Results are expressed in $\mathrm{kU} / \mathrm{ml}$, mean \pm S.E.M., $n=4$ to 10 ; ${ }^{*} P \leq 0.05$. Insert, IgG anti-dsDNA antibody titers were quantified by enzyme-linked immunosorbent assay in the serum of PBS-injected $\mathrm{Clu}^{-1-}$ and WT mice. (b) Ten weeks after the first injection of apoptotic cells, kidney sections from $\mathrm{Clu}^{-1-}$ and WT mice were stained with FITC-labeled anti-mouse lgG (left pictures) or unlabeled antiC4 revealed with a FITC-labeled anti-rat IgG antibodies (right pictures). Glomeruli were stained with DAPI (circles). Results are representative of four mice. (c) Spleens of WT and $\mathrm{Clu}^{-1-}$ mice were weighed 10 weeks after the first injection of apoptotic cells or PBS. Results are expressed in mg, mean \pm S.E.M., $n=4 ;{ }^{*} P \leq 0.05$. (d) The expression of the mRNA encoding SAP was analyzed by quantitative PCR in the livers from $\mathrm{Clu}^{-1-}$ and WT mice 10 weeks after the first injection of apoptotic cells or PBS. Results are expressed as a relative expression with GAPDH used as a calibrator, mean; \pm S.E.M., $n=5 ;{ }^{*} P<0.05$

molecule involved in the maintenance of tolerance to selfantigens.

After apoptotic cell engulfment, professional antigenpresenting cells (APCs) activate tolerogenic pathways that prevent local inflammatory reactions. ${ }^{44,48}$ They produce immunoregulatory cytokines (TGF $\beta$, IL-10) and low or no proinflammatory cytokines and chemokines. ${ }^{51}$ In this immunoregulatory environment, the presentation and crosspresentation of apoptotic cell antigens by APCs maintain peripheral T-cell tolerance. ${ }^{47,52}$ In contrast, in the absence of prompt clearance, apoptotic cells may evolve into immunologically harmful secondary necrotic cells which release danger signals that may favor the initiation of an autoimmune response. $^{27,53}$ Necrotic cells also trigger the production of inflammatory mediators by APCs. ${ }^{54} \mathrm{~A}$ rapid and efficient efferocytosis is thus required to maintain immune tolerance. In this study, we demonstrate that Clu, via its unique property to potentiate efferocytosis, prevents the in vivo generation of necrotic cells and thereby contributes to maintain selftolerance.

Despite the loss of billions of cells each day, the incidence of histologically detectable apoptotic cells is rare in normal tissues because of the efficiency of efferocytosis. ${ }^{22,44} \mathrm{We}$ showed that Clu binds specifically to late apoptotic cells, suggesting that, under normal physiological conditions, Clu will have only a minor role in apoptotic cell clearance. Accordingly, $\mathrm{Clu}^{-/-}$mice do not exhibit spontaneous signs of autoimmunity, as observed for most opsonin-deficient mice. Aged MBL-deficient mice do not develop autoimmunity even on a lupus-prone genetic background $129 \times \mathrm{C} 57 \mathrm{BL} / 6 .{ }^{55}$ Moreover, $\mathrm{SAP}^{-1-}$ and $\mathrm{C}_{1 \mathrm{q}^{-/-}}$mice only develop autoimmunity on the mixed $129 \times$ C57BL/ 6 or MRL/Mp background. ${ }^{30,31}$ To our knowledge, MFG-E8 ${ }^{-/}$mice are the only opsonin-deficient model that spontaneously develop an autoimmune phenotype with aging. ${ }^{29}$

The role of Clu in efferocytosis suggests the existence of endocytic receptor(s) for Clu. Megalin was described as a receptor for Clu involved in the uptake of Clu-associated misfolded proteins at the cerebral vascular endothelium and choroid epithelium $^{56}$ and in the endocytosis of cellular debris by epithelial cells. ${ }^{57}$ In humans, however, the expression of megalin is restricted to the proximal tubule of the kidneys, the choroid plexus epithelium, and ependymal cells lining the brain ventricules, ${ }^{58}$ making it unlikely to represent a major endocytic receptor for Clu-mediated efferocytosis by phagocytes. Accordingly, we failed to detect megalin by human $\mathrm{M} \varphi$ (unpublished observations). Recent studies have reported that Clu binds to some scavenger receptors ${ }^{5}$ and DC-SIGN, ${ }^{59}$ suggesting that these endocytic receptors may be involved in the internalization of Clu-opsonized apoptotic cells. Experiments are in progress to identify Clu-binding elements involved in the capture of late apoptotic cells by phagocytes.

We have observed that Clu binds specifically to blebs on late apoptotic cells, as reported for other opsonins, such as CRP and SAP. ${ }^{60}$ The fact that the binding of Clu is not dependent on the cell type nor on the apoptosis-inducing method suggested that the Clu-binding motifs are conserved molecules. We demonstrate here that Clu binds to histones. Previous studies have shown that core histone subunits rapidly accumulate in the cytoplasm of early apoptotic cells $^{61,62}$ before accumulation on blebs. ${ }^{36,63}$ Accordingly, we observed that histones are expressed by late but not early apoptotic cells, explaining the lack of binding of Clu to early apoptotic cells. These results confirm the role of histones as 'eat-me' molecules at the surface of late apoptotic cells.

Defects in apoptotic cell clearance and/or an excess of apoptotic cells make mice and humans susceptible to autoimmunity. ${ }^{28}$ Although efferocytosis is mediated by multiple and partly redundant mechanisms to avoid the initiation of an 
a

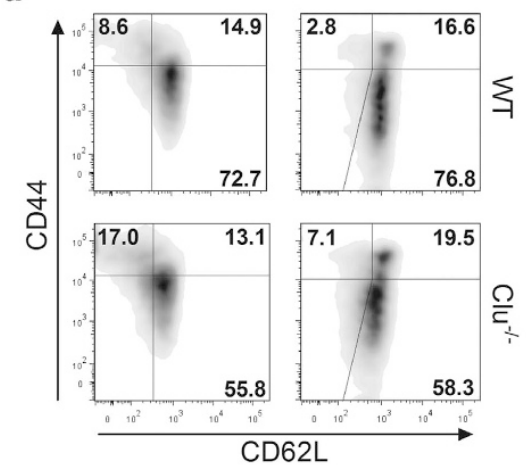

C

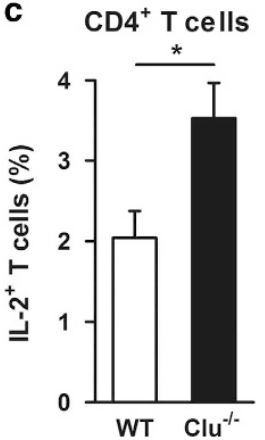

b

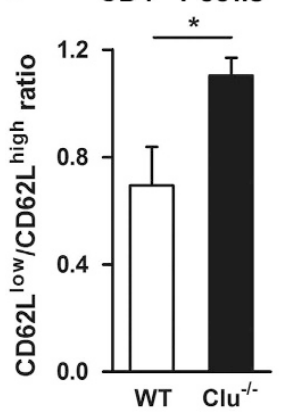

$\mathrm{CD}^{+} \mathrm{T}$ cells

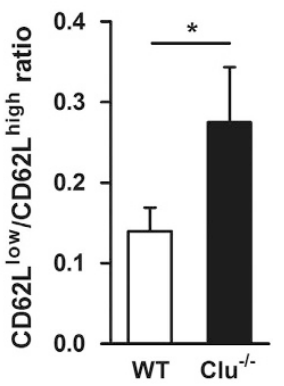

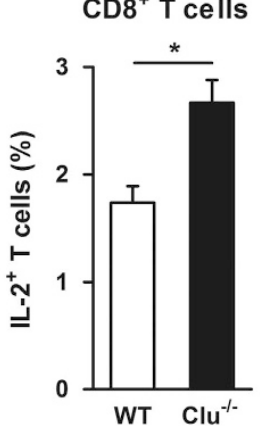

d

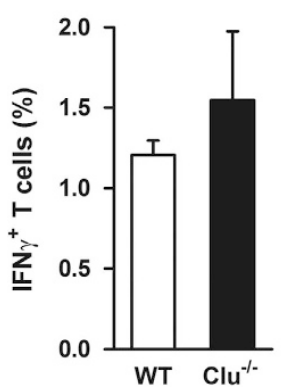

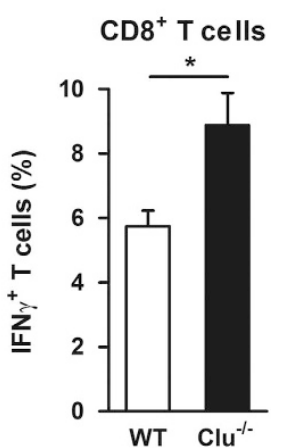

Figure 7 Memory T cells from apoptotic cell-injected Clu-deficient mice exhibit an activated phenotype. $\mathrm{Clu}^{-1-}$ and WT mice were injected with apoptotic cells once a week for 5 weeks. Two weeks after the first apoptotic cell injection, 4-6 mice per group were killed bimonthly. The phenotype and function of memory T cells was analyzed 10 weeks after the first injection in $\mathrm{Clu}^{-1-}$ and WT mice. (a) Lymph node cells were stained with PeCy5-labeled anti-CD3, APCeFluor 780-labeled anti-CD4 or -CD8, FITC-labeled antiCD62L, and PE-labeled anti-CD44 mAbs. Density plots represent cells gated on the $\mathrm{CD}^{+} \mathrm{CD}^{+}$(left) and $\mathrm{CD} 3^{+} \mathrm{CD} 8^{+}$(right) populations. Flow cytometric analysis identified CD44- ${ }^{-}$D62 $\mathrm{L}^{\text {high }}$ naive T cells, CD44 ${ }^{+} \mathrm{CD} 62 \mathrm{~L}^{\text {high }}$ central memory $\mathrm{T}$ cells, and $\mathrm{CD} 44^{+} \mathrm{CD} 62 \mathrm{~L}^{\text {low }}$ effector memory $\mathrm{T}$ cells. Values correspond to the percentage of each subset. (b) $\mathrm{CD}_{2} \mathrm{~L}^{\text {low/CD62L }} \mathrm{L}^{\text {high }}$ cell ratio among $\mathrm{CD}^{+} \mathrm{CD}^{+} \mathrm{CD} 44^{+}$(left histograms) and $\mathrm{CD}^{+} \mathrm{CD}^{+} \mathrm{CD}_{4} 4^{+}$(right histograms) cells in the lymph nodes of WT and $\mathrm{Clu}^{-1}-$ mice. (c and d) Lymph node cells from $\mathrm{Clu}^{-1-}$ and WT mice were stimulated in vitro with PMA plus ionomycin in the presence of brefeldin A, before staining with PeCy5-labeled antiCD3, FITC-labeled anti-CD4, APCeFluor 780-labeled anti-CD8, PE-labeled anti-IL-2, and APC-labeled anti-IFN $\gamma$ mAbs. Percentages of IL-2- (c) and IFN $\gamma$-secreting cells (d) among $\mathrm{CD}^{+} \mathrm{CD}^{+}$(left histograms) and $\mathrm{CD}^{+} \mathrm{CD}^{+}$(right histograms) are shown. (b-d). Mean \pm S.E.M., $n=4$ to $6 ;{ }^{*} P \leq 0.05$

autoimmune response, it has been reported that repeated injections of apoptotic cells may induce signs of autoimmunity (without clinical signs). ${ }^{49}$ Considering the role of $\mathrm{Clu}$ in efferocytosis, we hypothesized that an excess of apoptotic cells could be less efficiently cleared in $\mathrm{Clu}^{-1-}$ mice, leading to a more intense immune response. Indeed, we observed that $\mathrm{Clu}^{-1-}$ mice are more sensitive to apoptotic cell-induced autoimmunity. They develop signs of autoimmunity, such as immunoglobulin and complement component C4 deposition within kidneys, autoantibody production, and splenomegaly. In parallel, we observed an activation of effector memory apoptotic cell antigen-specific T cells in $\mathrm{Clu}^{-1-}$ mice. In line with these results, previous studies reported that, in models of autoimmune pancreatitis and myocarditis, $\mathrm{Clu}^{-1-}$ mice develop more severe inflammatory lesions than WT mice. ${ }^{14,15}$ However, the mechanism(s) involved in this protective role of Clu was not investigated. Considering our results, it is likely that, in these models associated with a massive cell death, the absence of Clu may have contributed to initiate apoptotic cell-driven autoimmunity.

In conclusion, we show that Clu is a non-redundant opsonin critically involved in the efferocytosis of late apoptotic cells and the maintenance of immune homeostasis. In vivo, Clu deficiency leads to a striking autoimmunity induced by the injection of apoptotic cells, a model that mimics a massive cell death that can occur during severe tissue injuries. These results also suggest that Clu may have a protective role against the establishment of chronic sterile inflammatory disorders. This study opens new insights into how to induce tolerance to self-antigens in autoimmune diseases and to optimize immunogenic cell death in antitumor immunotherapies.

\section{Materials and Methods}

Proteins and antibodies. Human $\mathrm{Clu}$ was purified from plasma, as previously described. ${ }^{7}$ Recombinant human MBL and human and murine Clu were from Biotechne (Lille, France). HSA, C1q, and FITC-labeled WGA were from SigmaAldrich (St. Louis, MO, USA). SAP (Calbiochem, Darmstadt, Germany), CRP (Millipore, Billerica, MA, USA), and $\mathrm{H} 1, \mathrm{H} 2 \mathrm{~A}, \mathrm{H} 2 \mathrm{~B}, \mathrm{H} 3$, and $\mathrm{H} 4$ histone subunits (New England Biolabs, Ipswich, MA, USA) were from the indicated providers. Proteins were labeled with Oregon green 488 dye (FluoReporter Oregon Green 488 Protein Labeling Kit; Invitrogen Molecular Probes, Carlsbad, CA, USA) or biotinylated (EZ-Link Sulfo-NHS-LC-Biotin Kit; Pierce, Rockford, IL, USA) using the commercial kits. The origins and clone numbers of the mAbs used in this study are listed in Table 1.

Isolation and generation of human leukocytes. Blood from healthy subjects was obtained from the Blood collection center of Angers (agreement ANG 2003-2). Human peripheral blood mononuclear cells (PBMCs) were isolated by 
Table 1 List of monoclonal antibodies (mAb) used

\begin{tabular}{|c|c|c|c|}
\hline mAb & Clone & Reactivity & Provider \\
\hline Anti-B220 & RA3-6B2 & Mouse & BD Pharmingen \\
\hline Anti-CD19 & MB19-1 & Mouse & eBioscience \\
\hline Anti-CD3 & $145-2 C 11$ & Mouse & eBioscience \\
\hline Anti-CD4 & L3T4 & Mouse & eBioscience \\
\hline Anti-CD8 & $53-6.7$ & Mouse & eBioscience \\
\hline Anti-CD44 & IM7 & Mouse & BD Pharmingen \\
\hline Anti-CD11b & $\mathrm{M} 1 / 70$ & Mouse & BD Pharmingen \\
\hline Anti-CD11c & N418 & Mouse & eBioscience \\
\hline Anti-CD14 & TUK4 & Human & Dako \\
\hline Anti-CD19 & MB19-1 & Mouse & eBioscience \\
\hline Anti-CD45RA & $\mathrm{HI} 100$ & Mouse & BD Pharmingen \\
\hline Anti-CD62L & MEL-14 & Mouse & eBioscience \\
\hline Anti-Clu & 350270 & Human & R\&D Systems \\
\hline Anti-dsDNA & HpS22 & Human/Mouse & Immunotools \\
\hline Anti-F4/80 & BM8 & Mouse & Invitrogen \\
\hline Anti-H2/H3/H4 & HB-9 & Human/Mouse & AbD Serotec \\
\hline Anti-H2-Kb & AF6-88.5 & Mouse & BD Pharmingen \\
\hline Anti-H4 & $\mathrm{F}-9$ & Human/Mouse & Santa Cruz Biotech \\
\hline Anti-HLA-DR & L243 & Human & BD Pharmingen \\
\hline Anti-IAb & $\begin{array}{l}\text { AF6-120.1 \& } \\
25-9-3\end{array}$ & Mouse & BD Pharmingen \\
\hline Anti-IFN $\gamma$ & 4S.B3 & Mouse & eBioscience \\
\hline Anti-IL-2 & JES6-5H4 & Mouse & eBioscience \\
\hline
\end{tabular}

Ficoll-Paque (Amersham Biosciences, Uppsala, Sweden) density-gradient centrifugation. To generate $M \varphi$, monocytes were purified from PBMC by positive selection using anti-CD14 mAb-coated magnetic beads (Miltenyi Biotech, Bergisch Gladbach, Germany); purity was $>99 \%$ (data not shown). Purified $\mathrm{CD} 14^{+}$ monocytes $\left(1 \times 10^{6}\right.$ cells $\left./ \mathrm{ml}\right)$ were differentiated into $\mathrm{M} \varphi$ by 5 -day culture with $20 \mathrm{ng} /$ $\mathrm{ml}$ M-CSF (Biotechne) and $2 \mathrm{ng} / \mathrm{ml} \mathrm{GM}$-CSF (CellGenix, Freiburg, Germany) in complete medium (CM), consisting of RPMl 1640 medium containing $2 \mathrm{mM}$ L-glutamine, antibiotics (all from Lonza, Verviers, Belgium), and 10\% (v/v) heatinactivated fetal calf serum (Biowest, Nuaillé, France). After Ficoll-Paque centrifugation, neutrophils were isolated from erythrocytes by $1.5 \%$ (w/v) dextran (Amersham Biosciences) density-gradient sedimentation. Contaminating red blood cells were lysed by hypo-osmotic shock. Purity was routinely $>98 \%$ (data not shown).

Isolation and generation of murine leukocytes. C57BL/6 mice and Ova-specific T-cell receptor transgenic mice OT1 and OT2 (C57BL/6 background) were from Charles River Laboratories (L'Arbresle, France). $\mathrm{Clu}^{-1-}$ mice (C57BL/6 background) were from The Jackson Laboratory (Bar Harbor, ME, USA). Mice were bred and housed in a pathogen-free environment. Experiments were conducted according to institutional guidelines and were approved by the institutional ethics committee of Région des Pays de la Loire (agreement 2009.18).

Murine $M \varphi$ and $D C$ generation: Non-myeloid bone marrow cells were removed after incubation of total bone marrow cells with $10 \mu \mathrm{g} / \mathrm{ml}$ anti-CD4, -CD8, -B220, and -I-Ab mAbs for 20 min at $4{ }^{\circ} \mathrm{C}$ and then with rabbit complement (SigmaAldrich) for $30 \mathrm{~min}$ at $37^{\circ} \mathrm{C}$. Bone marrow myeloid precursors were cultured for 7 days in CM containing $50 \mathrm{ng} / \mathrm{ml}$ M-CSF (Immunotools, Friesoythe, Germany) or $10 \mathrm{ng} / \mathrm{ml} \mathrm{GM}$-CSF (R\&D Systems, Abington, UK) to generate bone marrow-derived $\mathrm{M} \varphi$ (BMDM) and DCs (BMDCs), respectively. Non-adherent immature DCs were purified at day 5 by positive selection using anti-CD11c mAb-coated magnetic beads (Miltenyi Biotech). BMDM and BMDC populations contained $>95 \% \mathrm{CD}^{11 b^{+}}$

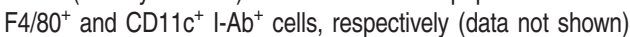

Murine $C D 8^{+}$and $C D 4^{+}$T-cell purification: $\mathrm{CD}^{+}{ }^{\top}$ cells from OT1 mice and $\mathrm{CD4}^{+} \mathrm{T}$ cells from OT2 mice were isolated from the spleen and lymph nodes using the $\mathrm{CD} 8^{+} \mathrm{T}$-Cell Isolation Kit II and the $\mathrm{CD}^{+} \mathrm{T}$-Cell Isolation Kit II, respectively, following the manufacturer's instructions (Miltenyi Biotech). Cell purity, determined by staining for CD3, CD4, CD8, and CD11c expression, was >99\% (data not shown).
Induction of cell death. Spontaneous human neutrophil and murine thymocyte apoptosis was induced by incubating cells in RPMI 1640 medium containing $1 \%$ FCS. Staining with allophycocyanin (APC)-labeled Ann V (BD Pharmingen, San Diego, CA, USA) and PI (Sigma-Aldrich) allowed to distinguish four cell populations by flow cytometry, corresponding to viable $\left(A n n \mathrm{~V}^{-} \mathrm{PI}^{-}\right)$, early apoptotic $\left(A n n \mathrm{~V}^{+} \mathrm{PI}^{-}\right)$, late apoptotic $\left(A n n \mathrm{~V}^{+} \mathrm{Pl}^{+}\right)$and secondary necrotic cells (Ann $\mathrm{V}^{+/}-\mathrm{PI}^{\text {high }}$ ). ${ }^{32}$ In some experiments, cell necrosis was induced by incubating cells at $56{ }^{\circ} \mathrm{C}$ for $30 \mathrm{~min}$. Apoptosis of the human T-cell line Jurkat (ATCC, Manassas, VA, USA) was induced by a 24-h incubation with $20 \mu \mathrm{g} / \mathrm{ml}$ etoposide (Sigma-Aldrich) or $20 \mathrm{ng} / \mathrm{ml}$ anti-FAS mAb (clone $\mathrm{CH}-11$; MBL International, Woburn, MA, USA). Before each experiment, the Ann V/PI staining was assessed to confirm cell apoptosis. In vivo apoptosis of cortical thymocytes was induced by injecting mice intraperitoneally with $0.2 \mathrm{mg}$ Dex (Calbiochem) per $25 \mathrm{~g}$ body weight. ${ }^{22,44}$ After $24 \mathrm{~h}$, the level of thymocyte apoptosis was evaluated by flow cytometry, as described above.

Binding assays. Apoptotic or necrotic cells $\left(1 \times 10^{5}\right.$ cells/well) were resuspended in PBS containing 1\% BSA (w/v) and incubated or not with $1 \mu \mathrm{M}$ OG-labeled human $\mathrm{Clu}$, recombinant $\mathrm{Clu}(\mathrm{rClu}), \mathrm{C} 1 \mathrm{q}$, or $\mathrm{HSA}$ for $20 \mathrm{~min}$ at room temperature. The binding of unlabeled Clu was detected with an anti-Clu mAb (Biotechne); mouse lgG1 antibody (R\&D Systems) was used as a control. Bound antibodies were detected with FITC-labeled anti-mouse lg Ab (BD Pharmingen). Fluorescence was analyzed by flow cytometry. In some experiments, apoptotic Jurkat $T$ cells (containing at least $60 \%$ Ann $\mathrm{V}^{+} \mathrm{Pl}^{+}$cells) were treated for $1 \mathrm{~h}$ with $500 \mu \mathrm{g} / \mathrm{ml}$ DNase or for $30 \mathrm{~min}$ with $100 \mu \mathrm{g} / \mathrm{ml}$ pronase (both from Roche, Mannheim, Germany) or for $4 \mathrm{~h}$ with protein deglycosylation mix (New England Biolabs) prior to the binding assay. In other experiments, binding of Clu to 'flip-flopped' erythrocytes ${ }^{64}$ was measured. The binding of Clu, SAP, CRP, and HSA to histone subunits and dsDNA was measured by a solidphase binding assay. Briefly, $1 \mu \mathrm{g} / \mathrm{ml}$ of each histone subunit was coated on 96-well plates in $50 \mathrm{mM} \mathrm{NaHCO} / \mathrm{Na}_{2} \mathrm{CO}_{3}$ buffer, $\mathrm{pH}=9.6$, for $12 \mathrm{~h}$ at $4{ }^{\circ} \mathrm{C}$. dsDNA was coated as previously described. ${ }^{44}$ After blocking the nonspecific sites with PBS containing $5 \% \mathrm{BSA}$, plates were incubated for $2 \mathrm{~h}$ with $1 \mu \mathrm{g} / \mathrm{ml}$ of biotinylated Clu, SAP, CRP, and HSA and then with HRP-labeled streptavidin (Diaclone, Besançon, France) diluted $1: 500$ for $1 \mathrm{~h}$. The coating of dsDNA was verified using an anti-dsDNA Ab (Immunotools) revealed by HRP-conjugated anti-mouse IgG Ab (Life Technologies, Saint Aubin, France). Optical density was read at $\lambda=492 \mathrm{~nm}$.

\section{Phagocytosis assays}

Phagocytosis assay with human cells: Freshly isolated neutrophils were labeled with the green fluorescent dye PKH67 using the PKH67 Green Fluorescent Cell Linker Kit (Sigma-Aldrich), according to the manufacturer's instructions. Apoptosis was induced as described above. $\mathrm{M \varphi}\left(2 \times 10^{5} \mathrm{cells} /\right.$ well) were cultured in 48-well plates for $12 \mathrm{~h}$ before the assay. PKH67-labeled early (corresponding to a cell population containing no late apoptotic cells) or late apoptotic neutrophils (corresponding to a cell population containing at least $80 \%$ late apoptotic cells) were incubated for $30 \mathrm{~min}$ in RPMI 1640 medium, containing or not $1 \mu \mathrm{M} \mathrm{Clu}$, MBL, or HSA. After washing, $1 \times 10^{6}$ neutrophils were added to $M \varphi$ and incubated for $40 \mathrm{~min}$ at $37^{\circ} \mathrm{C}$ in RPMI 1640 medium. Non-internalized apoptotic cells were removed by washing $M \varphi$ with ice-cold PBS. ${ }^{32}$ Cells were then incubated with an APC-labeled anti-HLA-DR mAb. Phagocytosis was analyzed by flow cytometry, as previously described. ${ }^{32}$ In some experiments, apoptotic neutrophils were incubated for $30 \mathrm{~min}$ in RPMI 1640 medium containing 30\% human serum, depleted or not in Clu, prior to the phagocytosis assay. Clu-depleted serums and control serums were prepared by passing human serums over a column of anti-Clu $\mathrm{mAb}$ or isotype control $\mathrm{mAb}$ covalently linked to agarose beads (co-IP columns; Pierce). Depletion was verified by quantifying Clu by ELISA (Biotechne); results showed that $89 \pm 2 \%$ (mean \pm S.E.M., $n=4$ ) of Clu was removed from the serum (not shown).

Phagocytosis assay with murine cells: Freshly isolated thymocytes from C57BL/6 mice were labeled with PKH67, prior to apoptosis induction. BMDM $\left(2 \times 10^{5}\right.$ cells/well) were cultured in 48-well plates for $12 \mathrm{~h}$ before the assay. Opsonization of apoptotic thymocytes (80\% late apoptotic cells) was performed as described above. After washing with ice-cold PBS, BMDM were incubated with phycoerythrin (PE)-labeled anti-F4/80 mAb. In some experiments, apoptotic thymocytes were incubated with $1 \%(\mathrm{v}: \mathrm{v})$ serum from WT or $\mathrm{Clu}^{-1-}$ mice, prior to incubation with BMDM. Results are expressed as a percentage of phagocytosis (percentage of $\mathrm{PKH} 7^{+}$events among the $\mathrm{HLA}^{-\mathrm{DR}^{+}}$or $\mathrm{F} 4 / 80^{+}$populations) or as a phagocytic index determined as follows: (percentage of phagocytosis $\times$ MFI of double-positive events) $/ 100{ }^{63}$ 
In vivo phagocytosis assay. Thymocytes from WT mice were labeled with PKH67 and apoptosis was induced as described above. Apoptotic thymocytes $\left(1 \times 10^{8}\right.$ cells containing at least $80 \%$ late apoptotic cells) were injected intravenously into $\mathrm{Clu}^{-1-}$ and WT mice. The frequencies of PKH67-labelled cells among splenocytes were analyzed by flow cytometry $2 \mathrm{~h}$ after injection.

In vitro activation of OT1 and OT2 cells. Ova (Affiland, Liege, Belgium) and BSA were first dialyzed and detoxified (EndoTrap system; Profos, Regensburg, Germany) before use. Thymocytes from outbred Swiss mice were pulsed with $35 \mu \mathrm{M}$ Ova or BSA by osmotic shock, as previously described, ${ }^{50,65}$ prior to apoptosis induction. Apoptotic thymocytes (containing at least $80 \%$ late apoptotic cells) were incubated or not with albumin or murine $\mathrm{rClu}$, in RPMI 1640 medium. After washing, $5 \times 10^{5}$ apoptotic thymocytes were co-cultured with $1 \times 10^{5}$ BMDCs and $1 \times 10^{5}$ OT1 or OT2 cells. After $24 \mathrm{~h}$, the production of IL-2 was monitored by ELISA (BD Pharmingen).

Laser confocal scanning microscopy. Human $M \varphi$ were cultured on glass slides in 48-well plates, $24 \mathrm{~h}$ prior to the phagocytosis assay. After

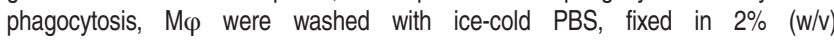
paraformaldehyde (PFA) in PBS and stained with a PE-labeled anti-CD14 mAb. Slides were then mounted with ProlonGold reagent (Invitrogen). In some experiments, apoptotic neutrophils were incubated with OG-Clu as described above and fixed with $2 \%$ PFA in PBS. In others, apoptotic neutrophils were stained with anti-H2/H3/H4 mAb; bound mAb were detected with a PE-labeled anti-mouse Ig Ab (Dako, Glostrup, Denmark). Cells were then mounted on glass slides with ProlonGold reagent after nucleus staining with DAPI (Invitrogen). Staining was analyzed with a confocal laser scanning system (A1Rsi, Nikon, Tokyo, Japan).

PCR analysis. The expression of the mRNA encoding SAP was analyzed in the livers from $\mathrm{Clu}^{-1-}$ and WT mice. Total RNA, purified using the RNeasy Plus MiniKit (Qiagen, Düsseldorf, Germany) was reverse transcribed using the superscript II Reverse Transcriptase (Invitrogen). mRNA expression was determined by reverse transcriptase-PCR using iQ SYBR Green Supermix (Bio-Rad, Hercules, CA, USA). Specific gene expression was calculated using the $2^{-\Delta C T}$ method (using GAPDH as a calibrator).

Induction and monitoring of autoimmunity in mice. WT and $\mathrm{Clu}^{-1-}$ mice (8-week old) were injected intravenously with $1 \times 10^{7}$ irradiated apoptotic cells (ATCC), once a week for 5 weeks (from week 1 to week 5). Serum samples were collected once every 2 weeks after the first injection, for up to 10 weeks (at week 2 , $4,6,8$, and 10). Serum anti-dsDNA IgG Ab were quantified by ELISA (Alpha Diagnostic International, San Antonio, TX, USA). Every 2 weeks, 4-6 mice from each group were killed, and the kidneys, spleen, and lymph nodes were recovered. Lymph node cells were stained with PE-Cy5-labeled anti-CD3, APCeFluor 780labeled anti-CD4 or anti-CD8 mAbs, FITC-labeled anti-CD19, PE-labeled antiCD44, and FITC-labeled anti-CD62L Abs. In some experiments, lymph node cells were stimulated in vitro with $10 \mathrm{ng} / \mathrm{ml}$ PMA and $1 \mu \mathrm{M}$ ionomycin for $6 \mathrm{~h}$ in the presence of $10 \mu \mathrm{g} / \mathrm{ml}$ brefeldin A (all from Sigma-Aldrich). Cells were then fixed for 10 min with 4\% PFA in PBS and incubated for 30 min in PBS containing $0.1 \%$ BSA and $0.1 \%$ saponin (both from Sigma-Aldrich) with PeCy5-labeled anti-CD3, FITC-labeled anti-CD4 mAb, APCeFluor 780-labeled anti-CD8, PE-labeled anti-IL-2, and APC-labeled anti-IFN $\gamma$ mAbs. Fluorescence was analyzed by flow cytometry. Kidneys were frozen, cryosected, and fixed in cold acetone. Tissue sections were stained with FITC-labeled goat anti-mouse IgG antibodies (Dako) or unlabeled rat anti-C4 mAb (Cedarlane, Burlington, Canada). Binding of anti-C4 mAb was detected with a FITC-labeled goat anti-rat Ig Ab (BD Biosciences, San Jose, CA, USA). After washing, DAPI was added and the cells were mounted on glass slides with ProlonGold reagent. Slides were examined using a Leica DMR fluorescence microscope with an IM500 image manager system (Leica, Wetzlar, Germany).

Statistical analysis. Data are shown as mean \pm S.E.M. or as a percentage of the increase $((B-A) / A) \times 100)$ or decrease $((A-B) / A) \times 100)$, where $A$ is the control value and $B$ the value obtained with the protein of interest, mean \pm S.E.M. Data were analyzed by the one-tailed Wilcoxon matched-pairs test or by the onetailed Mann-Whitney test or by two-way ANOVA test. $P \leq 0.05$ was considered statistically significant.

\section{Conflict of Interest}

The authors declare no conflict of interest.
Acknowledgements. This work was supported by institutional grants from Inserm (Institut National de la Santé et de la Recherche Médicale) and the University of Angers. Pierre Cunin received a grant from 'La Ligue Contre le Cancer'. Charline Miot received a grant from the 'Fondation pour la Recherche Médicale'. We thank members of the Blood collection Center of Angers for blood collection and members of PACeM (Plateforme d'Analyse Cellulaire et Moléculaire), SCAHU (Service Commun d'Animalerie Hospitalo-Universitaire), and SCIAM (Service Commun d'Imagerie et d'Analyses Microscopiques) facilities of the University of Angers for technical assistance.

\section{Author contributions}

PC, CB, YD, and PJ designed research; PC, CB, CM, JFA, FT, LP, SB, MS, EG, and IF performed research; $A C, J F A, J F S, P B$, and $M W$ contributed new reagents/analytic tools; PC, CB, CM, SB, LP, YD, and PJ analyzed data; and PC, CB, PJ, and YD wrote the paper.

1. Trougakos IP, Gonos ES. Clusterin/apolipoprotein $J$ in human aging and cancer. Int $J$ Biochem Cell Biol 2002; 34: 1430-1448.

2. Jenne DE, Lowin B, Peitsch MC, Bottcher A, Schmitz G, Tschopp J. Clusterin (complement lysis inhibitor) forms a high density lipoprotein complex with apolipoprotein A-I in human plasma. J Biol Chem 1991; 266: 11030-11036.

3. Hogasen K, Mollnes TE, Tschopp J, Harboe M. Quantitation of vitronectin and clusterin. Pitfalls and solutions in enzyme immunoassays for adhesive proteins. J Immunol Methods 1993; 160: 107-115.

4. Morrissey C, Lakins J, Moquin A, Hussain M, Tenniswood M. An antigen capture assay for the measurement of serum clusterin concentrations. J Biochem Biophys Methods 2001; 48: $13-21$.

5. Wyatt AR, Yerbury JJ, Berghofer P, Greguric I, Katsifis A, Dobson CM et al. Clusterin facilitates in vivo clearance of extracellular misfolded proteins. Cell Mol Life Sci 2011; 68: 3919-3931.

6. Wyatt AR, Yerbury JJ, Wilson MR. Structural characterization of clusterin-chaperone client protein complexes. J Biol Chem 2009; 284: 21920-21927.

7. Wilson MR, Easterbrook-Smith $\mathrm{SB}$. Clusterin binds by a multivalent mechanism to the $\mathrm{Fc}$ and Fab regions of IgG. Biochim Biophys Acta 1992; 1159: 319-326.

8. Tschopp J, Chonn A, Hertig S, French LE. Clusterin, the human apolipoprotein and complement inhibitor, binds to complement C7, C8 beta, and the b domain of C9. J Immunol 1993; 151: 2159-2165.

9. Silkensen JR, Schwochau GB, Rosenberg ME. The role of clusterin in tissue injury. Biochem Cell Biol 1994; 72: 483-488.

10. Bertram L, Tanzi RE. Alzheimer disease: new light on an old CLU. Nat Rev Neurol 2010; 6 : 11-13.

11. Partridge SR, Baker MS, Walker MJ, Wilson MR. Clusterin, a putative complement regulator, binds to the cell surface of Staphylococcus aureus clinical isolates. Infect Immun 1996; 64: 4324-4329.

12. Li DQ, Ljungh A. Binding of human clusterin by Staphylococcus epidermidis. FEMS Immunol Med Microbiol 2001; 31: 197-202.

13. Akesson P, Sjoholm AG, Bjorck L. Protein SIC, a novel extracellular protein of Streptococcus pyogenes interfering with complement function. J Biol Chem 1996; 271: 1081-1088.

14. McLaughlin L, Zhu G, Mistry M, Ley-Ebert C, Stuart WD, Florio CJ et al. Apolipoprotein J/ clusterin limits the severity of murine autoimmune myocarditis. J Clin Invest 2000; 106: $1105-1113$.

15. Savkovic V, Gantzer H, Reiser U, Selig L, Gaiser S, Sack U et al. Clusterin is protective in pancreatitis through anti-apoptotic and anti-inflammatory properties. Biochem Biophys Res Commun 2007; 356: 431-437.

16. Newkirk MM, Apostolakos P, Neville C, Fortin PR. Systemic lupus erythematosus, a disease associated with low levels of clusterin/apoJ, an antiinflammatory protein. J Rheumatol 1999; 26: $597-603$.

17. Devauchelle V, Essabbani A, De Pinieux G, Germain S, Tourneur L, Mistou S et al. Characterization and functional consequences of underexpression of clusterin in rheumatoid arthritis. J Immunol 2006; 177: 6471-6479.

18. Ravichandran KS, Lorenz U. Engulfment of apoptotic cells: signals for a good meal. Nat Rev Immunol 2007; 7: 964-974.

19. Jeannin $P$, Jaillon $S$, Delneste $Y$. Pattern recognition receptors in the immune response against dying cells. Curr Opin Immunol 2008; 20: 530-537.

20. Savill J, Hogg N, Ren Y, Haslett C. Thrombospondin cooperates with CD36 and the vitronectin receptor in macrophage recognition of neutrophils undergoing apoptosis. J Clin Invest 1992; 90: 1513-1522.

21. Ravetch JV, Kinet JP. Fc receptors. Annu Rev Immunol 1991; 9: 457-492.

22. Scott RS, McMahon EJ, Pop SM, Reap EA, Caricchio R, Cohen PL et al. Phagocytosis and clearance of apoptotic cells is mediated by MER. Nature 2001; 411: 207-211.

23. Kobayashi N, Karisola P, Pena-Cruz V, Dorfman DM, Jinushi M, Umetsu SE et al. TIM-1 and TIM-4 glycoproteins bind phosphatidylserine and mediate uptake of apoptotic cells. Immunity 2007; 27: 927-940. 
24. Gardai SJ, McPhillips KA, Frasch SC, Janssen WJ, Starefeldt A, Murphy-Ullrich JE et al. Cell-surface calreticulin initiates clearance of viable or apoptotic cells through transactivation of LRP on the phagocyte. Cell 2005; 123: 321-334.

25. Ogden CA, deCathelineau A, Hoffmann PR, Bratton D, Ghebrehiwet B, Fadok VA et al. C1q and mannose binding lectin engagement of cell surface calreticulin and CD91 initiates macropinocytosis and uptake of apoptotic cells. J Exp Med 2001; 194: 781-795.

26. Hanayama R, Tanaka M, Miwa K, Shinohara A, Iwamatsu A, Nagata S. Identification of a factor that links apoptotic cells to phagocytes. Nature 2002; 417: 182-187.

27. Munoz LE, Lauber K, Schiller M, Manfredi AA, Herrmann M. The role of defective clearance of apoptotic cells in systemic autoimmunity. Nat Rev Rheumatol 2010; 6: 280-289.

28. Nagata S, Hanayama R, Kawane K. Autoimmunity and the clearance of dead cells. Cell 2011; 140: 619-630

29. Hanayama R, Tanaka M, Miyasaka K, Aozasa K, Koike M, Uchiyama Y et al. Autoimmune disease and impaired uptake of apoptotic cells in MFG-E8-deficient mice. Science 2004; 304: 1147-1150.

30. Botto M, Dell'Agnola C, Bygrave AE, Thompson EM, Cook HT, Petry F et al. Homozygous C1q deficiency causes glomerulonephritis associated with multiple apoptotic bodies. Nat Genet 1998; 19: 56-59.

31. Bickerstaff MC, Botto M, Hutchinson WL, Herbert J, Tennent GA, Bybee A et al. Serum amyloid $\mathrm{P}$ component controls chromatin degradation and prevents antinuclear autoimmunity. Nat Med 1999; 5: 694-697.

32. Jaillon S, Jeannin P, Hamon Y, Fremaux I, Doni A, Bottazzi B et al. Endogenous PTX3 translocates at the membrane of late apoptotic human neutrophils and is involved in their engulfment by macrophages. Cell Death Differ 2009; 16: 465-474.

33. Trouw LA, Blom AM, Gasque P. Role of complement and complement regulators in the removal of apoptotic cells. Mol Immunol 2008; 45: 1199-1207.

34. Coleman ML, Sahai EA, Yeo M, Bosch M, Dewar A, Olson MF. Membrane blebbing during apoptosis results from caspase-mediated activation of ROCK I. Nat Cell Biol 2001; 3: 339-345.

35. Franz S, Herrmann K, Furnrohr BG, Sheriff A, Frey B, Gaipl US et al. After shrinkage apoptotic cells expose internal membrane-derived epitopes on their plasma membranes. Cell Death Differ 2007; 14: 733-742.

36. Radic M, Marion T, Monestier M. Nucleosomes are exposed at the cell surface in apoptosis. J Immunol 2004; 172: 6692-6700.

37. Barbulescu K, Meyer zum Buschenfelde KH, Neurath MF. Constitutive and inducible protein/ DNA interactions of the interferon-gamma promoter in vivo in [corrected] CD45RA and CD45R0 T helper subsets. Eur J Immunol 1997; 27: 1098-1107.

38. Dupuis G, Bastin B. Lectin interactions with the Jurkat leukemic T-cell line: quantitative binding studies and interleukin-2 production. J Leukoc Biol 1988; 43: 238-247.

39. Nauta AJ, Trouw LA, Daha MR, Tijsma O, Nieuwland R, Schwaeble WJ et al. Direct binding of $\mathrm{C} 1 \mathrm{q}$ to apoptotic cells and cell blebs induces complement activation. Eur J Immunol 2002; 32: $1726-1736$

40. Butler PJ, Tennent GA, Pepys MB. Pentraxin-chromatin interactions: serum amyloid P component specifically displaces $\mathrm{H} 1$-type histones and solubilizes native long chromatin J Exp Med 1990; 172: 13-18.

41. Du Clos TW, Zlock LT, Rubin RL. Analysis of the binding of C-reactive protein to histones and chromatin. J Immunol 1988; 141: 4266-4270.

42. Hess KL, Babcock GF, Askew DS, Cook-Mills JM. A novel flow cytometric method for quantifying phagocytosis of apoptotic cells. Cytometry 1997; 27: 145-152.

43. Gershov D, Kim S, Brot N, Elkon KB. C-reactive protein binds to apoptotic cells, protects the cells from assembly of the terminal complement components, and sustains an antiinflammatory innate immune response: implications for systemic autoimmunity. J Exp Med 2000; 192: 1353-1364.

44. A-Gonzalez N, Bensinger SJ, Hong C, Beceiro S, Bradley MN, Zelcer N et al. Apoptotic cells promote their own clearance and immune tolerance through activation of the nuclear receptor LXR. Immunity 2009; 31: 245-258.

45. Ferguson TA, Herndon J, Elzey B, Griffith TS, Schoenberger S, Green DR. Uptake of apoptotic antigen-coupled cells by lymphoid dendritic cells and cross-priming of CD8(+) T cells produce active immune unresponsiveness. J Immunol 2002; 168: 5589-5595.

46. Sauter B, Albert ML, Francisco L, Larsson M, Somersan S, Bhardwaj N. Consequences of cell death: exposure to necrotic tumor cells, but not primary tissue cells or apoptotic cells, induces the maturation of immunostimulatory dendritic cells. J Exp Med 2000; 191 423-434.

47. Steinman RM, Turley S, Mellman I, Inaba K. The induction of tolerance by dendritic cells that have captured apoptotic cells. J Exp Med 2000; 191: 411-416.
48. Mukundan L, Odegaard JI, Morel CR, Heredia JE, Mwangi JW, Ricardo-Gonzalez RR et al. PPAR-delta senses and orchestrates clearance of apoptotic cells to promote tolerance. Nat Med 2009; 15: 1266-1272.

49. Mevorach D, Zhou JL, Song X, Elkon KB. Systemic exposure to irradiated apoptotic cells induces autoantibody production. J Exp Med 1998; 188: 387-392.

50. Peng Y, Elkon KB. Autoimmunity in MFG-E8-deficient mice is associated with altered trafficking and enhanced cross-presentation of apoptotic cell antigens. J Clin Invest 2011; 121: $2221-2241$.

51. Fadok VA, Bratton DL, Konowal A, Freed PW, Westcott JY, Henson PM. Macrophages that have ingested apoptotic cells in vitro inhibit proinflammatory cytokine production through autocrine/paracrine mechanisms involving TGF-beta, PGE2, and PAF. J Clin Invest 1998; 101: 890-898.

52. McGaha TL, Chen Y, Ravishankar B, van Rooijen N, Karlsson MC. Marginal zone macrophages suppress innate and adaptive immunity to apoptotic cells in the spleen. Blood 2012; 117: 5403-5412.

53. Scaffidi $\mathrm{P}$, Misteli T, Bianchi ME. Release of chromatin protein HMGB1 by necrotic cells triggers inflammation. Nature 2002; 418: 191-195.

54. Fadok VA, Bratton DL, Guthrie L, Henson PM. Differential effects of apoptotic versus lysed cells on macrophage production of cytokines: role of proteases. J Immunol 2001; 166 : $6847-6854$

55. Stuart LM, Takahashi K, Shi L, Savill J, Ezekowitz RA. Mannose-binding lectin-deficient mice display defective apoptotic cell clearance but no autoimmune phenotype. J Immunol 2005; 174: 3220-3226.

56. Zlokovic BV, Martel CL, Matsubara E, McComb JG, Zheng G, McCluskey RT et al Glycoprotein 330/megalin: probable role in receptor-mediated transport of apolipoprotein $\mathrm{J}$ alone and in a complex with Alzheimer disease amyloid beta at the blood-brain and bloodcerebrospinal fluid barriers. Proc Natl Acad Sci USA 1996; 93: 4229-4234.

57. Bartl MM, Luckenbach T, Bergner O, Ullrich O, Koch-Brandt C. Multiple receptors mediate apoJ-dependent clearance of cellular debris into nonprofessional phagocytes. Exp Cell Res 2001; 271: 130-141.

58. Lundgren S, Carling T, Hjalm G, Juhlin C, Rastad J, Pihlgren U et al. Tissue distribution of human gp330/megalin, a putative $\mathrm{Ca}(2+)$-sensing protein. J Histochem Cytochem 1997; 45 383-392.

59. Sabatte J, Faigle W, Ceballos A, Morelle W, Rodriguez Rodrigues C, Remes Lenicov F et al. Semen clusterin is a novel DC-SIGN ligand. J Immunol 2011; 187: 5299-5309.

60. Rovere P, Manfredi AA, Vallinoto C, Zimmermann VS, Fascio U, Balestrieri G et al. Dendritic cells preferentially internalize apoptotic cells opsonized by anti-beta2-glycoprotein I antibodies. J Autoimmun 1998; 11: 403-411.

61. Gabler C, Blank N, Winkler S, Kalden JR, Lorenz HM. Accumulation of histones in cell lysates precedes expression of apoptosis-related phagocytosis signals in human lymphoblasts. Ann N Y Acad Sci 2003; 1010: 221-224.

62. Gabler C, Blank N, Hieronymus T, Schiller M, Berden JH, Kalden JR et al. Extranuclear detection of histones and nucleosomes in activated human lymphoblasts as an early event in apoptosis. Ann Rheum Dis 2004; 63: 1135-1144.

63. Frisoni L, McPhie L, Colonna L, Sriram U, Monestier M, Gallucci S et al. Nuclear autoantigen translocation and autoantibody opsonization lead to increased dendritic cell phagocytosis and presentation of nuclear antigens: a novel pathogenic pathway for autoimmunity? $\mathrm{J}$ Immunol 2005; 175: 2692-2701.

64. Familian A, Zwart B, Huisman HG, Rensink I, Roem D, Hordijk PL et al. Chromatinindependent binding of serum amyloid P component to apoptotic cells. J Immunol 2001; 167: 647-654.

65. den Haan JM, Lehar SM, Bevan MJ. CD8(+) but not CD8(-) dendritic cells cross-prime cytotoxic T cells in vivo. J Exp Med 2000; 192: 1685-1696.

Cell Death and Disease is an open-access journal published by Nature Publishing Group. This work is licensed under a Creative Commons Attribution 4.0 International License. The images or other third party material in this article are included in the article's Creative Commons license, unless indicated otherwise in the credit line; if the material is not included under the Creative Commons license, users will need to obtain permission from the license holder to reproduce the material. To view a copy of this license, visit http://creativecommons.org/licenses/by/4.0/ 